\title{
High Frequency, High Efficiency, and High Power Density GaN-Based LLC Resonant Converter: State-of-the-Art and Perspectives
}

\author{
Seyed Abolfazl Mortazavizadeh ${ }^{1}$, Simone Palazzo ${ }^{1}$, Arturo Amendola ${ }^{2}$, Enzo De Santis ${ }^{1}$, Dario Di Ruzza ${ }^{2}$, \\ Giuseppe Panariello ${ }^{2}$, Annunziata Sanseverino ${ }^{1}{ }^{1}$, Francesco Velardi ${ }^{1}$ and Giovanni Busatto ${ }^{1, *}$ \\ 1 Department of Electrical and Information Engineering, University of Cassino and Southern Lazio, \\ 03043 Cassino, Italy; abolfazl.mortazavizadeh@unicas.it (S.A.M.); simone.palazzo@unicas.it (S.P.); \\ enzo.desantis@unicas.it (E.D.S.); a.sanseverino@unicas.it (A.S.); velardi@unicas.it (F.V.) \\ 2 Rete Ferroviaria Italiana (RFI), 00161 Roma, Italy; amendola.arturo@yahoo.com (A.A.); \\ d.diruzza@rfi.it (D.D.R.); g.panariello@rfi.it (G.P.) \\ * Correspondence: busatto@unicas.it
}

\section{check for}

updates

Citation: Mortazavizadeh, S.A.; Palazzo, S.; Amendola, A.; De Santis, E.; Di Ruzza, D.; Panariello, G.; Sanseverino, A.; Velardi, F.; Busatto, G. High Frequency, High Efficiency, and High Power Density GaN-Based LLC Resonant Converter: State-of-the-Art and Perspectives. Appl. Sci. 2021, 11, 11350. https:// doi.org/10.3390/app112311350

Academic Editor: Jinsub Park

Received: 28 October 2021

Accepted: 25 November 2021

Published: 30 November 2021

Publisher's Note: MDPI stays neutral with regard to jurisdictional claims in published maps and institutional affiliations.

Copyright: (c) 2021 by the authors. Licensee MDPI, Basel, Switzerland. This article is an open access article distributed under the terms and conditions of the Creative Commons Attribution (CC BY) license (https:// creativecommons.org/licenses/by/ $4.0 /)$.

\begin{abstract}
Soft switching for both primary and secondary side devices is available by using LLC converters. This resonant converter is an ideal candidate for today's high frequency, high efficiency, and high power density applications like adapters, Uninterrupted Power Supplies (UPS), Solid State Transformers (SST), electric vehicle battery chargers, renewable energy systems, servers, and telecom systems. Using Gallium-Nitride (GaN)-based power switches in this converter merits more and more switching frequency, power density, and efficiency. Therefore, the present paper focused on GaN-based LLC resonant converters. The converter structure, operation regions, design steps, and drive system are described precisely. Then its losses are discussed, and the magnets and inductance characteristics are investigated. After that, various interleaved topologies, as a solution to improve power density and decrease current ripples, have been discussed. Also, some challenges and concerns related to GaN-based LLC converters have been reviewed. Commercially available power transistors based on various technologies, i.e., GaN HEMT, Silicon (Si) MOSFET, and Silicon Carbide (SiC) have been compared. Finally, the LLC resonant converter has been simulated by taking advantage of LTspice and GaN HEMT merits, as compared with Si MOSFETs.
\end{abstract}

Keywords: LLC; resonant converter; GaN HEMT; review

\section{Introduction}

Resonant converters are soft switching topologies that can be employed either in Zero-Voltage Switching (ZVS) or Zero-Current Switching (ZCS) mode to reduce the turn-on or turn-off losses of power transistors [1]. Therefore, they can operate at high switching frequencies, hundreds $\mathrm{kHz}$ to $\mathrm{MHz}$ range, without unacceptable switching losses [2].

Resonant converters can be classified according to the LC network arrangement [3]. A series resonant converter contains a resonant element, inductor and capacitor connected in series to the load. Such converters, normally used with the maximum $100 \mathrm{kHz}$ frequency, do not have a good performance when the load varies in a wide range. Considering a parallel arrangement for the LC network results in a Parallel Resonant Converter (PRC). This type of resonant converter works in a wide range of loads, from zero to full load. It is usually preferred for short circuit protection, but it suffers from low efficiency. A series-parallel hybrid resonant converter, also called a multi resonant converter, combines the merits of both converters mentioned. Various arrangements have been introduced for multi-converters, like LLC, LCC, LCLC, and LCCL converters. Among them, the LLC converter, which uses the serial connection of resonant inductor (L), sum of all transformer inductances, i.e., main and leakage inductance $(\mathrm{L})$, and a resonant capacitor $(\mathrm{C})$, is the best known one [4]. 
LLC converter, first proposed by Yang in 2003, benefits from soft switching for both primary and secondary side devices [5]. LLC resonant converter, with such advantages as high frequency, high efficiency, and high power density, has a wide range of applications, including adapters, UPS, electric vehicle battery chargers, renewable energy systems, servers, and telecom systems [6-11]. Low EMI and wide voltage range are the other advantages of the LLC resonant converter [12-15].

ZVS maintained by the LLC converter enables a low turn-off current for primary switches. Therefore, $\mathrm{dv} / \mathrm{dt}$ at the primary switches is small [16]. Also, the LLC converter has the benefit of ZCS for the Synchronous Rectifiers (SRs) in frequencies lower than the resonant frequency [16-23]. Consequently, beside galvanic isolation, it achieves higher frequency with better efficiency, more power density, and lower total cost, as compared with the soft-switching PWM converters [11,19,21,24]. For high input voltage applications, the LLC topology is more effective in achieving higher efficiency because the switching losses are more dominant than the conduction ones [25-28].

In a promising development, GaN-based transistor is introduced as a very hard, mechanically stable wide bandgap semiconductor. With higher breakdown strength, faster switching speed, higher thermal conductivity, and lower on-resistance, GaN based transistors, also called GaN High Electron Mobility Transistors (GaN HEMT), significantly outperform silicon-based devices. Optimized internal structure and smaller chip size, along with lower drain-source resistance in the on-state condition, lead to the shorter deadtime and higher efficiencies, normally exceeding $96 \%$ [24]. Less capacitance, resulting in fewer losses while charging and discharging, less power consumption for driving the circuit, and lower price are the other advantages of using GaN-based transistors in the LLC converters [29].

Recent developments in LLC resonant converters with GaN transistors and novel magnetics present more and more switching frequency, power density, and efficiency [11,30-32]. Since GaN-based LLC converters are employed at very high frequencies, even higher than $500 \mathrm{kHz}$, full ZVS should be guaranteed because even a portion of hard switching could lead to shoot-through, severe thermal stress, and, finally, the device failure [6].

Ultra-high power density achieved by utilizing GaN HEMT switches in the LLC converter makes it an ideal choice for commercial applications such laptop adaptors and flat screen TVs, all-in-one desktops, and cell-phone fast chargers [25].

However, the most important problem with GaN HEMTs is the inherent normally on state of typical HEMT devices; this has been solved in most current available switches available in the market [33]. Also, there are some challenges GaN HEMTs face in LLC resonant converters, like digital control system design, PCB winding for $\mathrm{MHz}$ range switching frequency, flux cancellation techniques, EMI noise cancellation, and the current conductive limitation of a single GaN switch [11,30,34-41].

\section{LLC Resonant Converter Structure}

The general structure of the LLC resonant converter is shown in Figure 1. It consists of square generator (also called square wave generator), resonant tank, transformer, and rectifier. An EMI filter can also be added in the output port optionally.

By switching the square wave generator, either half-bridge or full-bridge topology, in a variable frequency with the fixed duty cycle, the DC gain of the resonant converter is varied to regulate the output voltage.

Both square wave generator in the primary side and rectifier in the secondary one can be half-bridge or full-bridge, depending on the application. Full-bridge topology has several advantages when compared with the half-bridge, like the two-fold voltage and the half current, less reverse voltage across secondary switches and better use of the transformer by using more power switches. Regarding the transformer, although a half-bridge requires half of the primary number of turns for the same voltage gain and magnetic flux swing and, thus, half of the primary winding resistance, the primary copper losses are still twice when compared to the full-bridge because the squared RMS current in 
the half-bridge case is four times more [2]. The output low-pass filter is commonly made up by a capacitor in parallel to the output rectifier instead of a LC filter, because the series filter inductance would be connected in series with the resonant inductance, affecting the resonance and, thus, the behavior of the converter.

Normally, Pulse-Frequency Modulation (PFM) is used to regulate the output power of the LLC converter.

Beside the above-mentioned advantages, if the switching frequency drifts away from the resonant frequency, the circulation current will be increased; then the efficiency and performance would be degraded. A large resonant inductor is necessary to support a wide voltage range. Such a large resonant inductor ends in a high RMS current, flux, and peak voltage [26,42-44].

Although a higher frequency is preferred because it equals higher power density and efficiency, there is always a trade-off between ensuring the maximum frequency and covering a wide input voltage range. Since they have a narrow input voltage range, a large capacitor is required in the input to support the required holdup time that degrades the power density [2]. It is suggested to add a small capacitor in series with the resonant inductor to maintain the same holdup time with a capacitor with half size [2].

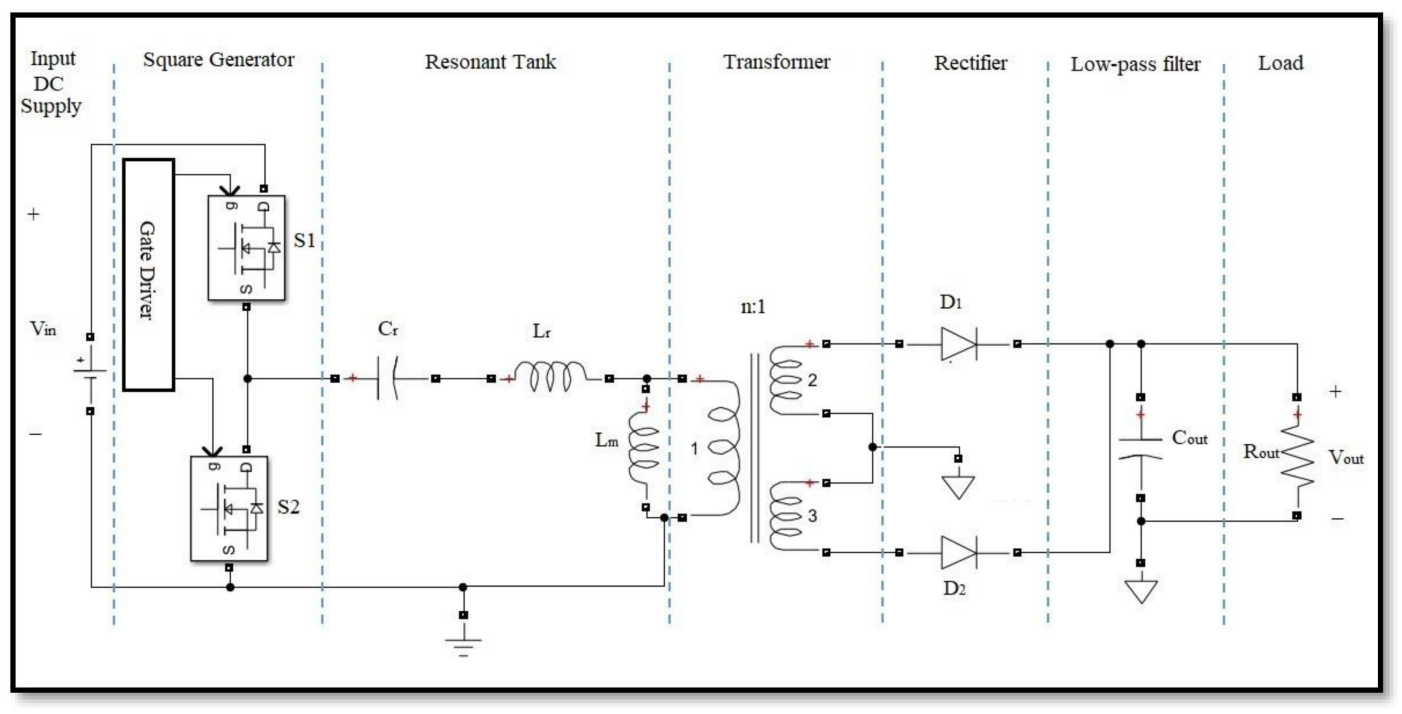

Figure 1. General circuit diagram of the LLC resonant converter.

There have been several revisions in the LLC resonant converter structure to expand the output voltage range. Mishima and Yeon, for instance, added an extra capacitor in parallel with an inductor to form an anti-resonant LC circuit [45,46]. By using this technique, the voltage gain becomes zero at the resonant frequency of the anti-resonant circuit and the input impedance will be infinite. In a reduced frequency range, wide range voltage regulation would be available. It should be noted that this converter is very sensitive to the switching frequency for the low output voltage levels.

In $[47,48]$, an additional switch is added to the primary side of the LLC converter to generate various AC input voltage levels. In the proposed structure, various voltage gains are achieved in the predefined frequency range. However, this technique suffers from more cost, conduction loss, and switching loss because of an additional switch and, also, the uneven current distribution between switches.

Using the cascaded rectifier in the secondary side of the LLC resonant converter has been proposed in some researches [49-51]. However, the need for complex coding for the controller and uneven current sharing among switches are the disadvantages of this technique.

Using semi-active reconfigurable rectifiers with reduced frequency range or even fixed switching frequency has also been proposed to expand the voltage range [52-56]. The 
secondary side switches have to be turned off with a high current. Also, the system overall cost, complexity, and volume will be increased.

An improved LLC converter with two resonant tanks has been proposed in [57]. Two different operation modes with two DC voltage gains are considered. Despite high efficiency at the full load, this technique suffers from the low one at light load condition.

A hybrid LLC resonant converter with a dual phase structure and three operating modes is proposed in [58]. The dual-phase structure allows the turn-off of one phase at the light load condition, when the output power is below half of the rated power to improve the converter's efficiency.

\section{Operation Regions}

According to the switching frequency, the LLC converter operation can be divided into three regions, as shown in Figure 2.

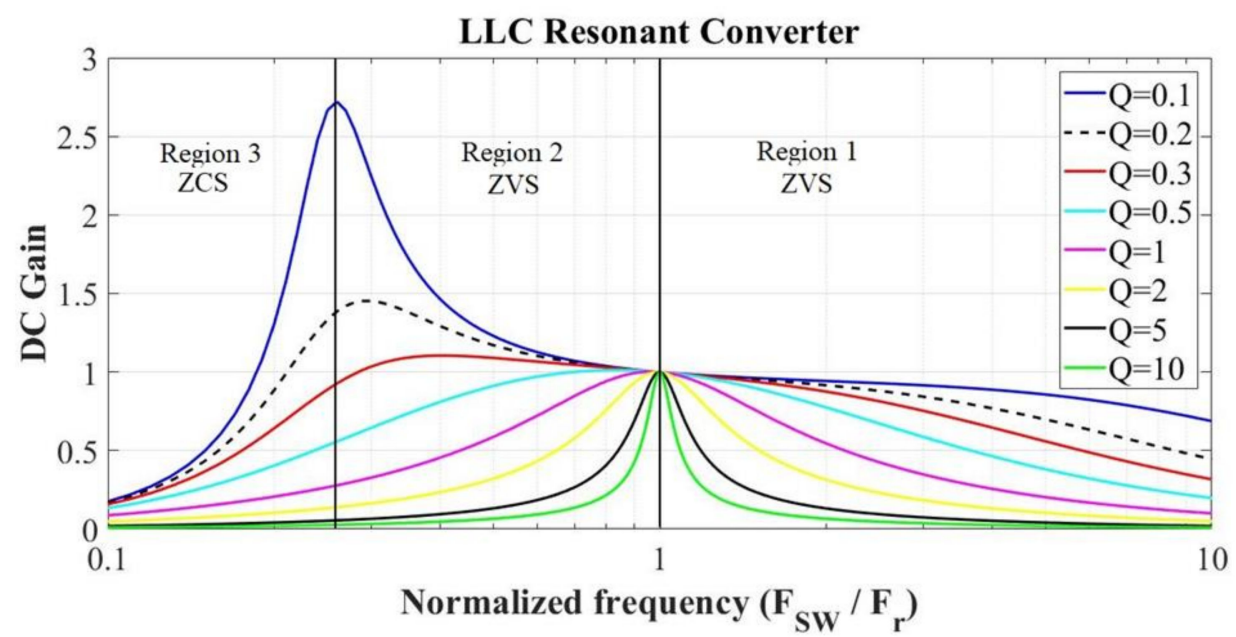

Figure 2. LLC resonant converter operation regions.

Either the input or output voltage fluctuation in the LLC converter yields the intense decrease in its efficiency [59]. In order to have a constant DC voltage in the output side, the LLC converter has to work in the ZVS region in which the switching frequency $\left(f_{S W}\right)$ is smaller than the resonant frequency $\left(f_{r}\right)$, i.e., region 2 in Figure 2. In this region, the primary and secondary side switches work in ZVS and ZCS situations, respectively. In order to ensure ZVS in region 2, the sufficient peak of the magnetizing current and enough deadtime to charge or discharge all parasitic capacitors are required [6]. Due to ZVS in the primary side and ZCS in the secondary one, region 2 is commonly used for DC transformer applications [60].

Also, region 1 in Figure 2 provides ZVS in a larger frequency range. If the LLC resonant converter is used in a wide output voltage range application by switching modulation frequency, region 1 is preferred. Theoretically, region 1 ensures wider switching modulation ranges, while the load varies in a wide range. It should be noted that if the input DC voltage is increased, ZVS can be partially maintained for primary side switches and the remaining hard-switching yields more heat and power loss [6]. Various control methods have been proposed to improve light load efficiency in LLC resonant converters [34,46,61,62].

In order to adjust the output power, the LLC converter normally operates with vary ing switching frequency, instead of duty cycle control, above the resonant frequency [24]. Increasing frequency equals to reducing the output power.

When the switching frequency is lower than the resonant frequency, i.e., $f_{S W} / f_{r}<1$, the circulating power is enhanced, resulting in the increase of conduction loss and current stress [63]. 


\section{LLC Converter Design Steps}

In order to design an LLC resonant converter, some critical parameters, including transformer turns ratio, quality factor, inductance ratio, resonant network parameters, and deadtime, should be determined. Also, the required DC gain should be calculated. The LLC converter design procedure is as follows:

\subsection{Selection of the Transformer Turn Ratio}

The transformer turn ratio, $n$, can be selected optimally as follows [64]:

$$
n=\frac{V_{d c \_n o m} / 2}{V_{o}+V_{\text {diode_drop }}+V_{\text {loss_margin }}}
$$

Considering various losses in the transformer and passive components, the loss margin is taken typically to be $0.2 \mathrm{~V}$ for low-voltage high-current applications.

\subsection{The DC Gain Requirements}

According to the application requirements, the LLC resonant converter should be designed in such a way that would meet all load conditions. Therefore, the maximum and minimum required DC gain, $M_{\max }$ and $M_{\min }$ can be calculated based on the maximum and minimum input voltage, $V_{i n \_m a x}, V_{i n \_ \text {min }}$, respectively, by using the following equations [4]:

$$
\begin{aligned}
M_{\text {max }} & =\frac{n V_{0 \_ \text {max }}}{V_{\text {in_min }} / 2} \\
M_{\text {min }} & =\frac{n V_{0 \_ \text {min }}}{V_{\text {in_max }} / 2}
\end{aligned}
$$

where $V_{o_{-} \max }$ and $V_{o_{-} \min }$ are the maximum and minimum allowed output voltage, respectively.

\subsection{Quality Factor and Inductance Ratio Selection}

Since the DC gain in resonant converters depends on the operating switching frequency, the conventional state space method cannot be used anymore. Instead, the Fundamental Harmonic Analysis (FHA) model could be applied [64]. The time-domain equations for the LLC resonant converter are also presented in [65] based on Time Interval Analysis (TIA).

By using the FHA model, the DC source and half-bridge/full-bridge network are replaced by the ideal sinusoidal AC source with fundamental frequency, $f_{n}$. By applying some simplifications, the LLC converter DC gain can be expressed in terms of the inductance ratio, $L_{n}$, and quality factor, $Q$, as follows [4]:

$$
M=\left|\frac{L_{n} f_{n}^{2}}{\left(L_{n}+1\right) f_{n}^{2}-1+j\left[\left(f_{n}^{2}-1\right) f_{n} Q L_{n}\right]}\right|
$$

where the quality factor of the series resonant circuit, $Q$, is defined as follows [4]:

$$
Q=\frac{\sqrt{L_{r} / C_{r}}}{R_{a c}}
$$

Many design procedures have been presented [64,66,67]. Among them, we preferred to use the procedure by De Simone et al., which allowed us to obtain the circuit parameters without any recursive calculations, starting from the set of converter specifications.

Inductance ratio, $L_{n}$, is defined as a ratio of the magnetizing inductance, $L_{m}$, to the series resonant inductance, $L_{r}$. A smaller magnetizing inductance will increase the magnetizing current and, consequently, conduction loss. To have a smaller magnetizing inductance that can aid ZVS, a smaller inductance ratio is required. 


\subsection{Resonant Component Selection}

According to [66], once that the output voltage $V_{0}$, the output current $I_{0}$, the input voltage range $V_{\text {in_min }}, V_{\text {in_max }}$ and the resonant frequency $f_{r}$ are defined, it is possible to obtain the circuit parameters.

Firstly, the maximum and minimum DC gain $M_{\max }, M_{\min }$, the transformer turn ratio $n$, and the maximum switching frequency $f_{\max }$ are calculated. Then, the equivalent $\mathrm{AC}$ resistance of load, $R_{a c}$, which refers to the transformer primary side is calculated as follows:

$$
R_{a c}=\frac{8 n^{2}}{\pi^{2}} \frac{V_{o}}{I_{o}}=\frac{8 n^{2}}{\pi^{2}} R_{\text {load }}
$$

where $R_{\text {load }}$ is the converter load resistance.

Also the ratio $L_{n}$ of the magnetizing inductance of the transformer and the resonant inductor can be derived. The maximum value for $Q$ is calculated as the minimum value between the $Q$ needed to work in the ZVS operating region at minimum input voltage and full load condition and the $Q$ needed to work in the ZVS region at no-load condition and maximum input voltage.

By knowing $L_{n}, Q, R_{a c}$, and $f_{r}$, the value of the resonant tank capacitor $C_{r}$ can be obtained:

$$
C_{r}=\frac{1}{2 \pi f_{r} Q R_{a c}}
$$

Thus, the resonant inductor and magnetizing inductance can be found using the following equation:

$$
\begin{gathered}
L_{r}=\frac{1}{\left(2 \pi f_{r}\right)^{2} C_{r}} \\
L_{m}=L_{n} L_{r}
\end{gathered}
$$

The deadtime, DT, can be calculated as follows [6]:

$$
D T \geq 8 L_{m} f_{s} C_{t}
$$

where $f_{s}$ is the switching frequency, $L_{m}$ is the transformer magnetizing inductance, and $C_{t}$ is the total parasitic capacitance seen in the primary side [6,68-70].

\section{Results}

Although LLC converter brings ZVS for turn-on, there are some other losses in the steady state [71]: (1) reverse conduction or circulating loss, especially when the LLC converter is operating at the step-up mode with a switching frequency lower than the resonant frequency; (2) conduction loss that happens in the on-state mode because of the on-state resistance of the transistor; (3) turn-off loss, especially when the LLC converter is working at the step-down mode with a switching frequency higher than the resonant frequency; and (4) gate drive loss, especially in high switching frequencies.

The parasitic components of the circuit play a more important role in the higher frequency. The LLC performance can shift away from the desired operating point by ignoring these components [72]. The effects of the parasitic capacitance of the secondary side diodes on the ZVS operation have been studied in some researches, like [6,68-70,73]. However, experimental tests have proved that the impact of parasitic capacitors and secondary side diodes is not limited to the ZVS condition and they can also influence the waveforms of the following normal operation [74]. The parasitic capacitance of the secondary side devices is more important in the LLC converter with step-up transformers, as discussed in $[70,75]$.

Conduction loss is strongly affected by transformer stray capacitance. This capacitance changes the magnetizing current and deadtime, deteriorating the LLC performance in the high switching frequency [76-78]. The lower parasitic winding capacitance contributes to smaller deadtime and higher efficiency. The stray capacitance not only distorts the 
transformer voltage in light load condition, but also generates common mode noise $[79,80]$. The effect of this capacitance on the LLC converter performance has been studied in some researches $[69,81]$. Watanabe et al., for instance, studied the dissipation caused by capacitance between primary and secondary windings of planar transformers in the LLC converter [82]. Two models called cylindrical and flat model have been proposed by Wang et al. to calculate the primary and secondary windings turn-to-turn capacitance [76]. A three-port network of six lumped capacitors, as introduced in [83], can also be used to analyze the inter-winding capacitance between primary and secondary windings. Lumped stray capacitance modeling is more convenient for dynamic circuit modeling and numerical simulation [78].

\section{LLC resonant Converter Drive}

As mentioned in section II, the control strategy of the LLC resonant converter is based on the Frequency Modulation (FM) of the gate input signals of primary bridge switches. If the primary stage is a half bridge, the leg is driven in a complementary way with $\sim 50 \%$ duty cycle, with adequate deadtime, as defined in Equation (10). In the case of a full bridge on the primary stage, the second leg is driven at the opposite of the first one.

If the rectifier is made up of controllable switches, i.e., it is a synchronous rectifier, it also needs an accurate driving circuit that can minimize power dissipation by bypassing the body diodes for the majority of each conduction period. Normally, the synchronous rectifier is controlled by a smart IC driver that senses the drain to the source voltage of each rectifier MOSFET to determine the source to drain current and turn on each gate rapidly at the start of each conduction cycle and turn off in close proximity to the zero current transitions for each branch of the output rectifier circuit.

The switching frequency, $f_{s w}$, is changed in order to stabilize the output voltage to the desired value thanks to a closed loop control whose simple block scheme is reported in Figure 3. The relationship between the switching frequency and the output voltage is defined in Equation (4), since $f_{s w}=f_{n} f_{r}$.

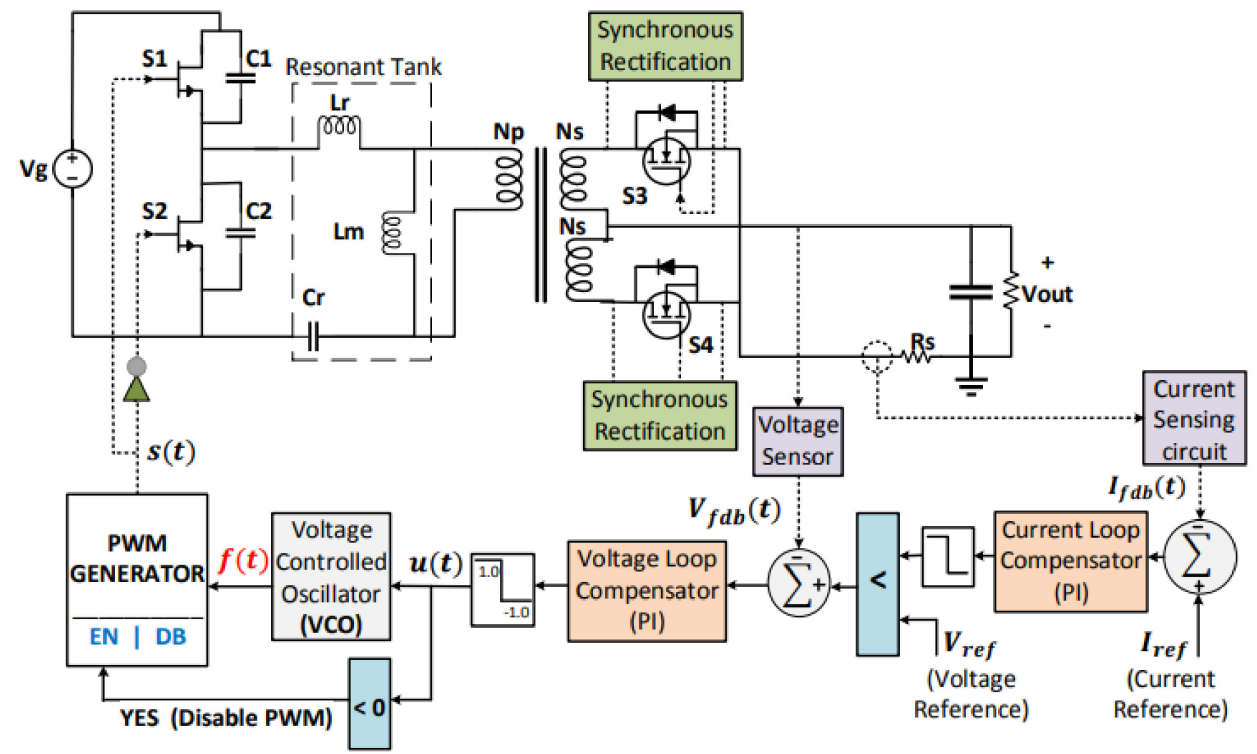

Figure 3. LLC converter and its closed loop control scheme.

Considering the gate drive losses, for a common driver, they can be estimated according to the equation:

$$
P_{d}=C_{g} V_{D}^{2} f_{s w}
$$

This equation shows a linear relationship between the driver losses and the switching frequency. For this reason, increasing the switching frequency in modern applications requires the optimization of the driving technique to avoid more power loss in the 
driver $[84,85]$. Moreover, another important aspect for the gate drive is the presence of parasitic components in the circuit. As the frequency is increased, the variation of voltage and current becomes faster, involving the dynamic of stray capacitances and inductances of the circuit. Phenomena like false trigger, voltage overshoot and ringing can occur, thus increasing the total power dissipation on the driver and causing the gate-source voltage to have an unexpected behavior, which can compromise the correct operations of the switch [86,87].

Overall, during the last years, some different works concerning the optimal driving of MOSFETs and GaN HEMTs have been published; in some cases, novel driver topologies have been developed [88-90]. Thus, the only way to achieve very high switching frequencies and keep power losses low is using resonant drivers, as shown in $[84,85,91,92]$. This technique exploits the resonance between the input capacitance of the power device and an external small inductor in order to create a series resonance, as shown in Figure 4. By modulating the driver's p-MOSFET and n-MOSFET in an appropriate way, it is possible to control the resonance current flowing through the inductor to obtain an impulsive current that turns on and off the gate of the power device. At the same time, the commutations of the driver's devices are soft and the switching power losses are heavily reduced. In fact, the power dissipation of the driver circuit can be reduced at:

$$
P_{d}=k C_{g} V_{D}^{2} f_{s w}
$$

where $k$ is a constant depending on the characteristic impedance of the resonant circuit and gate resistance; it is less than 1 [90].

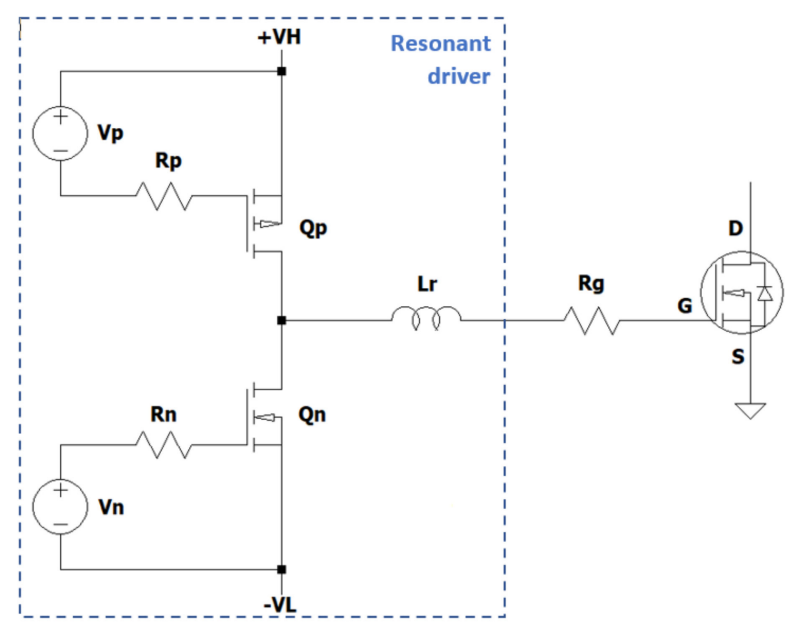

Figure 4. The simplest scheme of a resonant driver.

With the aim of working with GaN HEMTs at very high switching frequencies, there are some commercial drivers recommended by the manufacturers to achieve good performances in terms of rise and fall time, maximum propagation delay, thermal shutdown and jitter, both for low-side applications and half bridge [93-95]. While the low-side driving is quite easy to realize, the high-side requires more care, especially in terms of noise coupling and isolation. The most common high-side driver topologies are the isolated gate driver and the bootstrap, as shown in Figure 5. The first one uses an isolated DC/DC power supply to derive the driver voltage with respect to the floating node of the half bridge. 


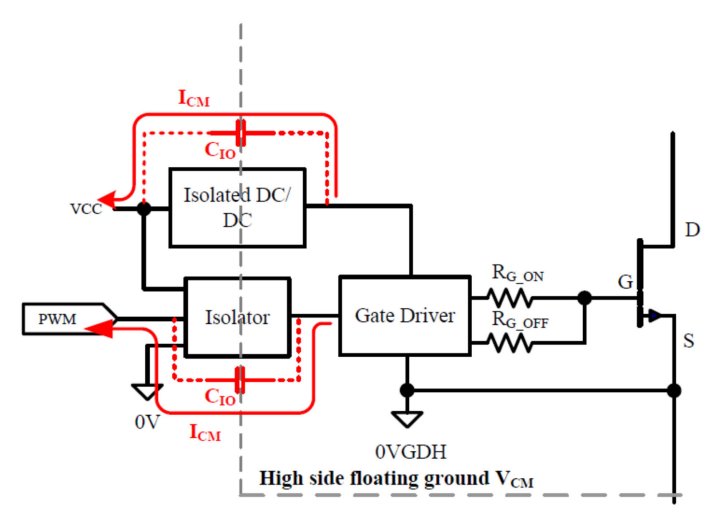

(a)

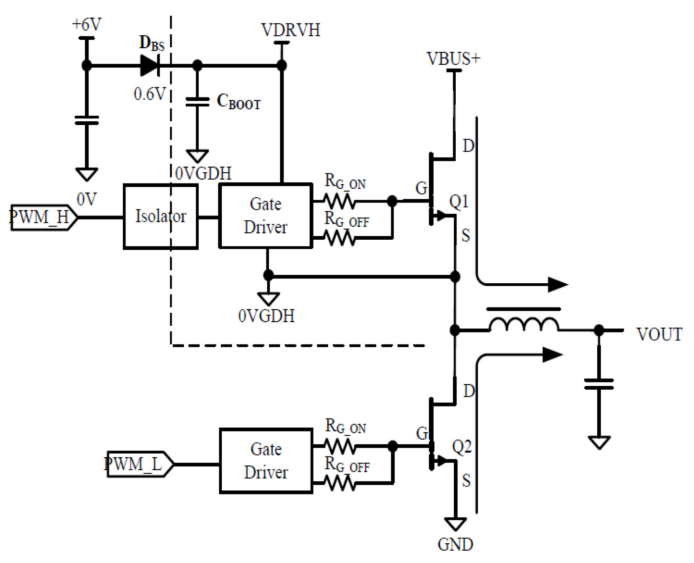

(b)

Figure 5. Most common high-side driver topologies: (a) isolated driver; and (b) half bridge driver with bootstrap.

Moreover, it has the best performance; also, it is the most used one, especially for high voltage applications. The bootstrap driver is more common for low voltage applications $(<100 \mathrm{~V})$ because of its lower cost and simpler circuit, even if it requires post regulation or voltage clamping.

\section{Interleaved LLC Resonant Converter}

In order to increase output power and reduce the current ripples, both in input and output ports, interleaved LLC resonant converter can be used. High power LLC converters with more than $3 \mathrm{~kW}$ power level are introduced using the multiphase technique with more components, volume, weight, cost, and complexity of current sharing [11]. Two and three phase LLC converters can achieve higher efficiency, as reported in the literature [49,96-99]. In order to optimize the magnetic components, there is a trade-off between the winding and core loss of the transformer.

Various arrangements have been introduced for the three phase interleaved LLC converter to achieve automatic current sharing, like Y-primary, Y-secondary, and primary delta capacitor network [100-103]. Interconnecting the primary sides to a common floating Y-node and interleaving the switches provide automatic current sharing between phases even if there is unbalance between the resonant components of the phases. It also helps in reshaping the current waveform and reduction of the RMS current [19]. Moving the Y-node to the secondary side offers the benefit of automatic current sharing, but the secondary winding current would be doubled, leading to more winding loss [102,103]. Using deltaconnection for both primary and secondary side windings can reduce the current by a factor of $\sqrt{3}$. It means that the winding loss will reduce to one third, while the voltage ${ }^{*}$ second is increased by a factor of $\sqrt{3}$ [103].

By using interleaved topologies, the primary and secondary side RMS current could be reduced due to the interaction between phases and flux cancellation [100-102]. Yang et al. integrated all inductors and transformers into one magnetic component to reduce cost and volume [102]. Another three phase interleaved LLC converter has been proposed by Nakakohara et al. for high voltage application, but it needs an additional balancing transformer [104].

By increasing switching frequency, integrated magnetics with PCB windings, as proposed in [11], can achieve higher efficiency and reduced common mode noise. Older LLC converters without GaN transistors were operating at around $100 \mathrm{kHz}$ with bulky magnetics. Thus, implementing integrated magnetics with PCB could be very difficult and expensive [11]. 


\section{LLC inductance and Magnetics}

Magnetizing inductance with a small value is necessary to achieve ZVS in the LLC resonant converter. In order to have a more miniaturized structure, many researchers have proposed topologies to utilize the LLC transformer leakage inductance as a resonant inductance instead of an external inductance [105-110]. Thus, an optimized design of the transformer would be necessary to avoid excessive losses.

In order to achieve higher power density and lower magnetic core loss, an integrated LLC transformer with stacked planar cores has been proposed in $[17,111]$. This technique can achieve flux cancellation between cells. Also, PCB winding is shaped near the airgap to reduce the fringing loss. $\mathrm{PCB}$ winding transformers can improve the reliability for the automated manufacturing process in MHz LLC converters [30,112,113].

Magnetic integration is necessary for three phase LLC converters, because they need three individual inductors and three individual transformers which degrade the LLC converter benefits in power density and cost [11].

Another integrated transformer with " $\infty$ " winding structure is proposed in [114]. In order to further reduce terminal loss and winding loss caused by leakage flux, the SR devices are mounted on the PCB board [114,115]. The matrix transformer is another solution proposed in the literature for flux cancellation, core size reduction, and loss reduction $[17,31,116,117]$. A numerical loss analysis, as given in [25] for matrix transformer selection, in an LLC converter benefits from the GaN HEMT transistor. Parallel connection of GaN HEMTs, in addition to the matrix transformer, is suggested in [31] to achieve more output current, but it is difficult to drive them synchronously. It makes the system vulnerable to unbalanced current and current overshoot, resulting in lower reliability.

Considering high switching frequency in the converter, fringing loss due to the airgap cannot be neglected anymore [17]. The shaped winding and gapped or notched winding are proposed to reduce the fringing effect in the transformer $[118,119]$.

The magnetic components for LLC converters operating below $100 \mathrm{kHz}$ still face some challenges in regard to size and complexity [11]. With the help of GaN HEMT devices, the switching frequency pushed to the $\mathrm{MHz}$ range and other problems will arise like skin effect, proximity effect, and fringing effect $[6,120,121]$. Also, the PCB transformer solution, as proposed in the literature, will intensify these effects [112]. A test-based method for core loss and copper loss evaluation is proposed in [120] to optimize the transformer in the MHz LLC converter.

\section{Commercial Availability}

The power switches used in the LLC resonant converter should support some key requirements including: low conduction loss originating from on-state resistance, fast operation, which means zero turn-on and turn-off time, less gate-driving power consumption originating from parasitic capacitors, small packaging, and low price [64,122].

The total loss resulting from a power switch can be classified into driving loss, conduction loss, and switching loss [25]. A GaN HEMT like GS55504B has all three mentioned advantages over its Si MOSFET counterpart, like IPx65R110CFD, when used in a high frequency LLC resonant converter.

Compared to Si-based Field Effect Transistor (FET), GaN HEMT has lower output capacitance and reduced deadtime for ZVS; also, circulating currents allow higher magnetizing inductance to reduce the magnetic fringing losses [114]. As well, its much lower gate input charge results in the reduced gate driver loss.

Material properties in three power switches from different types are listed in Table 1. $E_{g}, E_{B R}, V_{s}$, and $\mu$ are the bandgap energy, critical electric field for the breakdown in crystal, saturated drift velocity and mobility of electrons, respectively. 
Table 1. Material properties in Gallium-Nitride (GaN), Silicon (Si), and Silicon Carbide (SiC)-based switches.

\begin{tabular}{cccc}
\hline Properties & GaN & Si & SiC \\
\hline $\mathrm{E}_{\mathrm{G}}(\mathrm{eV})$ & 3.4 & 1.12 & 3.2 \\
$\mathrm{E}_{\mathrm{BR}}(\mathrm{MV} / \mathrm{cm})$ & 3.3 & 0.3 & 2.2 \\
$\mathrm{n}_{\mathrm{i}}\left(\mathrm{cm}^{-3}\right)$ & $2 \times 10^{-10}$ & $1 \times 10^{10}$ & $8 \times 10^{-9}$ \\
$\mathrm{~V}_{\mathrm{S}}\left(\times 10^{7} \mathrm{~cm} / \mathrm{s}\right)$ & 2.5 & 1.0 & 2.0 \\
$\mu_{\mathrm{n}}\left(\mathrm{cm}^{2} / \mathrm{Vs}\right)$ & $990-2000$ & 1500 & 650 \\
$\lambda(\mathrm{W} / \mathrm{cmK})$ & 1.3 & 1.5 & 3.8 \\
\hline
\end{tabular}

Also, three power switches from $\mathrm{GaN}, \mathrm{Si}$ and $\mathrm{SiC}$ with similar voltage and current rating available in the market are compared in the results presented in Table 2.

Table 2. Comparison of 650 V Field Effect Transistor (FET) switches available in the market from $\mathrm{GaN}, \mathrm{Si}$, and $\mathrm{SiC}$ technology.

\begin{tabular}{cccc}
\hline $\begin{array}{c}\text { Technology } \\
\text { /Parameter }\end{array}$ & GaN & Si & SiC \\
\hline Part number & GS66508B-TR & FCB099N65S3 & SCT3080AW7TL \\
Manufacturer & GaN Systems & ON Semiconductor & ROHM \\
Semiconductor \\
Drain-source voltage (V) & 650 & 650 & 650 \\
Drain current-continuous (A) & 30 & 30 & 29 \\
Rds-on $(m \Omega)$ & 63 & 99 & 104 \\
Vgs $(\mathrm{V})$ & $-10,+7$ & 4.5 & 5.6 \\
Qg-gate charge (nC) & 6.1 & 61 & 48 \\
Price $\$$ & 15.75 & 3.67 & 12.67 \\
\hline
\end{tabular}

\section{GaN-Based LLC Converter}

The use of $600 \mathrm{~V}$ E-mode GaN HEMTs has been proposed in [2] to expand the LLC resonant converter input voltage range from $340-400 \mathrm{~V}$ to $280-400 \mathrm{~V}$. This LLC resonant converter with GaN HEMT has $140 \mathrm{~W}$ /inch3 power density, which is 2-3 times better than its silicon MOSFET counterpart.

By the substitution of silicon FET with GaN HEMT in a $300 \mathrm{~W}$ AC-DC converter operating at $<100 \mathrm{kHz}$ with a power density of $8-10 \mathrm{~W} /$ inch3, operation in $500 \mathrm{kHz}$ switching frequency with $29 \mathrm{~W} /$ inch3 power density can happen [123].

The researchers are moving toward applications with higher voltage levels. Multilevel converter topologies have been studied widely to adapt high input voltage with low voltage devices [124,125]. Qi et al. presented the superior performance of $900 \mathrm{~V}$ GaN HEMT in a $300 \mathrm{kHz} 2 \mathrm{~kW}$ LLC resonant converter bridging high voltage and low voltage systems [126]. All GaN power supply units including the LLC converter with $3.2 \mathrm{~kW}$ power rating and $73 \mathrm{~W} /$ inch3 power density are also reported in the literature [127]. Further, using GaN HEMT instead of Silicon (Si) MOSFET resulted in 100\% power density improvement in a $150 \mathrm{~W}$ commercial adapter [128].

Silicon-based conventional resonant converters in the power range of $1-3 \mathrm{~kW}$ normally operate with a frequency up to $350 \mathrm{kHz}[1,129]$. A resonant converter with the frequency of $1 \mathrm{MHz}$ and peak efficiency of $94.1 \%$ is enabled using GaN HEMT in [130]. By using monolithic high voltage GaN power ICs that integrate GaN HEMT with the gate drive circuit in a small package, higher efficiency up to $98.3 \%$ has been reported for the LLC resonant converter operating in $1 \mathrm{MHz}$ switching frequency in a $3.2 \mathrm{~kW}$ power supply [131]. It should be noted that designing the drive circuit for E-mode GaN devices needs a tightly regulated power supply and a voltage clamping mechanism to prevent the excessive gate voltage [132].

As an example, a $2.5 \mathrm{~kW}$ LLC converter with $48 \mathrm{~V}$ output and 270-330 V input is con sidered. The design of the converter has been carried out according to the test procedure 
defined in Section 4, choosing a half bridge at the primary side of the converter and a synchronous rectifier at the secondary side. The parameters used for the design are listed in Table 3. Figure 6, instead, reports the schematic of the converter used for LTSpice simulations.

Table 3. Design parameters of the LLC 48 V $2.5 \mathrm{~kW}$ converter.

\begin{tabular}{cccc}
\hline Parameter & Value & Parameter & Value \\
\hline $\mathrm{n}$ & 3 & $\mathrm{f}_{\mathrm{r}}$ & $130 \mathrm{kHz}$ \\
$\mathrm{M}_{\max }$ & 1.11 & $\mathrm{Q}_{\mathrm{nom}}$ & 0.61 \\
$\mathrm{M}_{\min }$ & 0.91 & $\mathrm{Q}_{\max }$ & 0.68 \\
$\mathrm{~L}_{\mathrm{n}}$ & 4.85 & $\mathrm{~L}_{\mathrm{m}}$ & $27.9 \mu \mathrm{H}$ \\
$\mathrm{R}_{\mathrm{ac}, \min }$ & $6.97 \Omega$ & $\mathrm{L}_{\mathrm{r}}$ & $5.7 \mu \mathrm{H}$ \\
$\mathrm{R}_{\mathrm{ac} \text {, nom }}$ & $7.66 \Omega$ & $\mathrm{C}_{\mathrm{r}}$ & $260 \mathrm{nF}$ \\
\hline
\end{tabular}
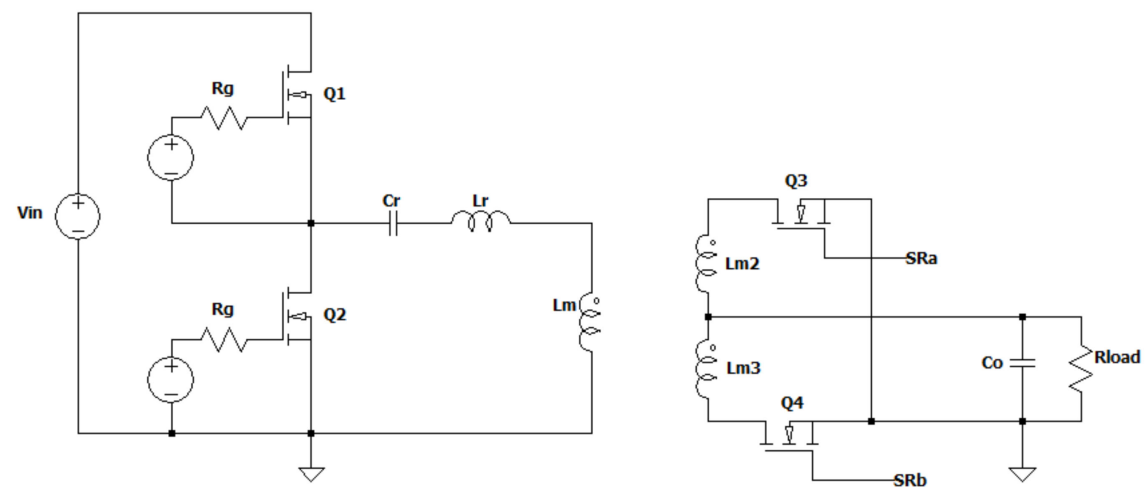

Figure 6. Schematic of the $2.5 \mathrm{~kW}-48 \mathrm{~V}$ LLC converter implemented in LTSpice.

Figures 7 and 8 show the results obtained by using the simulator for the total power dissipation and efficiency versus the switching frequency for two different technologies of the primary bridge devices Q1 and Q2. The first one is made up of $650 \mathrm{~V}$ Cool MOS IPW65R019C7 by Infineon. The second one is realized with $650 \mathrm{~V}$ GS66508 GaN devices by GaN Systems. Synchronous Rectifier devices Q3 and Q4 simulations have been performed by varying the input voltage and controlling the switching frequency in order to regulate the output voltage to the desired value of $48 \mathrm{~V}$.

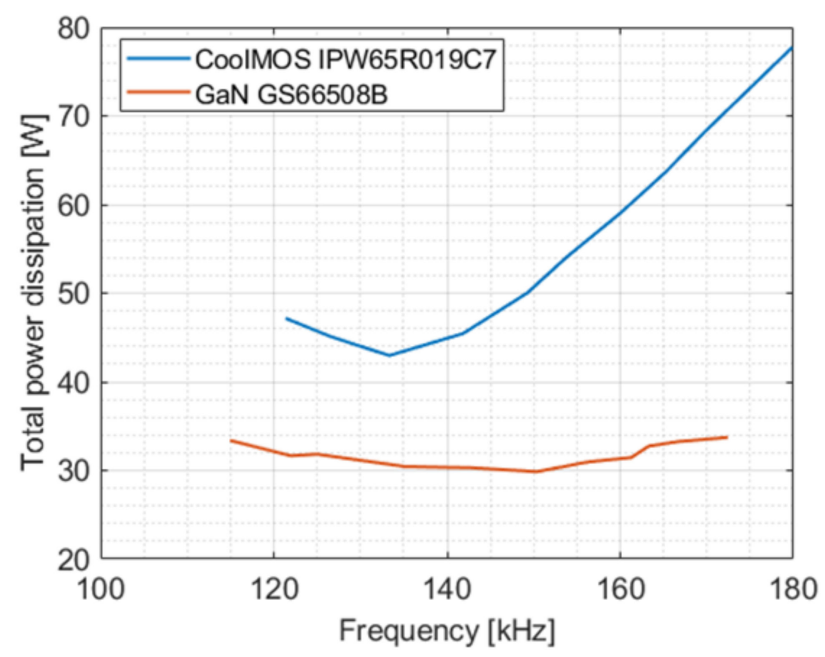

Figure 7. Comparison of total power dissipation vs. frequency for CoolMOS and GaN technologies for the $2.5 \mathrm{~kW}-48 \mathrm{~V}$ LLC converter. 


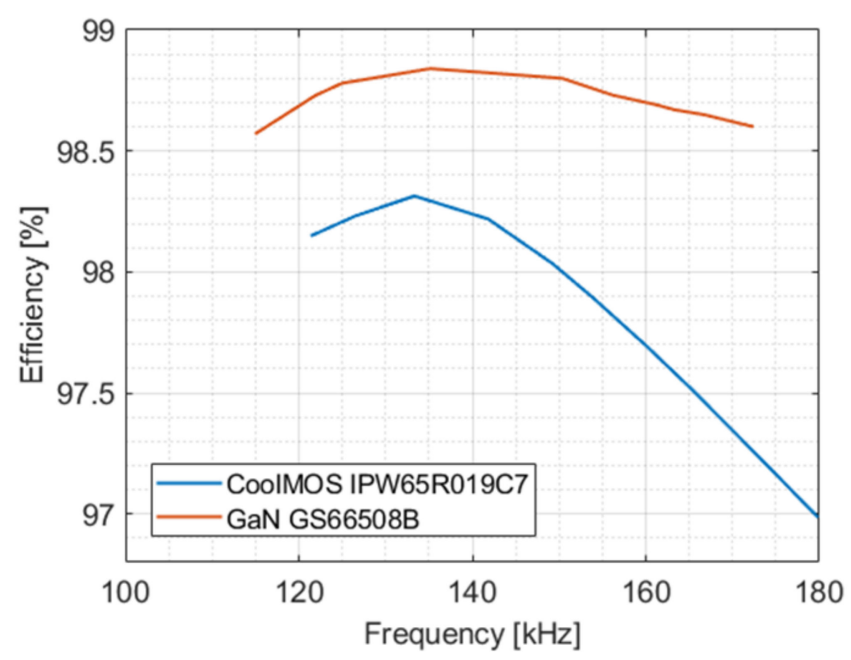

Figure 8. Comparison of converter efficiency vs. frequency for CoolMOS and GaN technologies for the $2.5 \mathrm{~kW}-48 \mathrm{~V}$ LLC converter.

As shown in the figures, the use of GaN technology permits the reduction of power losses, hence improving the efficiency in the whole regulation range. At the same time, it would be possible to shift the switching frequency range at higher frequencies to reduce the size of the magnetics and increase the power density.

Higher switching frequencies up to $27 \mathrm{MHz}$ are reported in the literature for an output power lower than $300 \mathrm{~W}$ without sacrificing efficiency or voltage gain [133-136]. Besides, power added efficiencies higher than $53 \%$ at $10 \mathrm{GHz}$ and the maximum operating frequency around $100 \mathrm{GHz}$ have been reported for GaN-based HEMTs in telecommunication applications [137,138].

Since GaN HEMT-based resonant converters operate at much higher switching frequencies, an additional challenge in the bridgeless converters is the presence of high frequency Common-Mode (CM) noise at the AC input [139]. Thus, a CM filter should also be considered. It has been shown that GaN HEMT has a worse behavior on the EMI test, as compared with MOSFETs, due to constraints of parasitic parameters in the filter design [41].

GaN-based LED driver consisting of a buck-boost PFC and an LLC resonant DC-DC converter has been presented in [140] with the high power density of $50 \mathrm{~W} /$ inch3, while replacing bulky electrolytic capacitors with low energy density ceramic ones.

\section{Reliability of GaN-Based Devices}

Using GaN HEMT has the special advantage of better performance under extreme temperatures, as what is reported for the short time operation at $1000{ }^{\circ} \mathrm{C}$ in vacuum; also, high radiation hardness makes it a reliable candidate for aerospace and military applications $[1,64,141-143]$.

Despite excellent features reported for GaN-based HEMTs, some issues still limit their performance, such as dispersion effects, trapping effect, parasitic effects, and reliability for long-term stability [144].

Failure mechanism identified on GaN HEMTs can be classified into thermally-activated mechanisms, mechanisms related to the presence of hot electrons, and GaN devices' specific mechanisms due to its polar and piezoelectric nature [145]. Temperature as an accelerating factor for passivation stability results in gate-metal interconnect degradation, feed metal interconnect degradation, ohmic contact degradation and thermally-induced delamination of passivation [144]. The presence of hot electrons accelerated by the high longitudinal electric field as a common degradation factor in all high-voltage FETs and the dominant failure mechanism in the GaN HEMTs can lead to electron trapping in SiN, crystallographic damage and hot electrons trap generation [144-149]. 
It has been demonstrated that parasitic effects leading to current collapse can be reduced by passivating surface states using deposited grown $\mathrm{SiN}$ and controlling the electric field with field-plates $[150,151]$. For commercially available GaN devices at $200{ }^{\circ} \mathrm{C}$ channel temperature, the Median Time To Failure (MTTF) is reported in order of $10^{7}$, which is an excellent value [152].

Moreover, many different studies on the short circuit characterization of GaN HEMTs have been performed in [153-156], showing the results of finite element simulations and experimental tests in different conditions. In [153], short circuit test on $650 \mathrm{~V}$ GaN HEMTs is conducted when the drain voltage is greater than $350 \mathrm{~V}$. Simulation results showed that in these test conditions, a very high-power density was dissipated in a critical region of the device and it was intensified by significant current focalization, as proved by experimental observations.

It has been demonstrated that the temperature in the critical region can reach the maximum allowable temperature for a GaN/AlGaN structure and bring the device to failure. Further details are provided in [154,155], where two kinds of failure are described for $650 \mathrm{~V} \mathrm{GaN} \mathrm{HEMTs} \mathrm{non-destructive} \mathrm{short} \mathrm{circuit} \mathrm{tests.} \mathrm{The} \mathrm{first} \mathrm{one} \mathrm{involves} \mathrm{a} \mathrm{large}$ amount of energy causing the increase of the temperature, which exceeds the melting temperature of the metallization of drain contacts. The second failure mechanism happens at higher drain voltages, but the damaged area is smaller and it is located below the source field plate at the gate edge on the drain side.

An analysis of the influence of environmental adaptability on key characteristics of GaN HEMTs has been conducted in [157] by temperature cycling, high temperature storage, and steady-state operation life tests. The drain current of all the GaN HEMTs has risen after the tests, possibly due to the increasing concentration of 2-D electron gas in the channel. Before and after the tests, the threshold voltage for GaN HEMTs had decreased and there was no obvious trend in the gate-to-source leakage current variation for these devices.

In assessing the reliability of AlGaN/GaN HEMTs for high voltage applications, the reverse-bias voltage is introduced as the key factor based on High Temperature Reverse Bias (HTRB) stress [158]. In addition to destructive results like permanent degradation in on-state current, transconductance, and voltage threshold shifts, some positive effects have been reported like the decrease of gate leakage current, improved gate lag characteristics, and a decrease of current collapse during pulsed measurement during the whole test.

Another relevant issue when working with GaN HEMTs is discussed in [156], where some problems related to the drain current measurement are shown. In particular, although the use of shunt resistors is one of the best ways to measure the current in very high frequency applications, it can distort the measurement because of the presence of parasitics. In this work, a simple method to solve this problem is presented and experimentally validated.

\section{Conclusions}

A comprehensive review of the LLC resonant converter was presented in this paper. LLC resonant converter has great advantages like high frequency, high efficiency, and high power density in a wide range of applications. Using GaN HEMT switches instead of $\mathrm{Si}$ MOSFETs will improve the afore-mentioned advantages of the LLC converters.

The most important challenge for GaN HEMTs, like normality on HEMT devices and the proposed solution, have been introduced here. Also, challenges GaN HEMTs faces, like digital control system design, $\mathrm{PCB}$ winding for $\mathrm{MHz}$ range switching frequency, flux cancellation techniques, EMI noise cancellation, and current conductive limitation of a single GaN switch, have been listed.

Using interleaved topologies offers some benefits. There are also considerations discussed thoroughly. An important consideration for power switches is the reliability covered here. Finally, some commercially available power switches from various generations, i.e., Si MOSFET, SiC, and GaN HEMT, have been compared. The simulation results approved the superiority of GaN-based HEMTs. 
Author Contributions: Conceptualization, S.A.M. and S.P.; software, S.A.M. and S.P.; writingoriginal draft preparation, S.A.M. and S.P.; writing-review and editing, E.D.S., G.P., A.S. and F.V.; supervision, G.B.; project administration, A.A. and D.D.R.; funding acquisition, G.B. All authors have read and agreed to the published version of the manuscript.

Funding: This work has been supported by Rete Ferroviaria Italiana-RFI under the contract "Convertitori e alimentatori switching per cabine IS" (Sp.T. RFI-AD.RS.SSA0011P20190000003_1) and partially by the Ministry of University and Research as Research Projects of National Relevance n: 2017 WA5ZT3.

Institutional Review Board Statement: Not applicable.

Informed Consent Statement: Not applicable.

Conflicts of Interest: The authors declare no conflict of interest.

\section{References}

1. Cornelius, A.; Hensel, A.; Wienhausen, H.A.; Kranzer, D. Application of GaN Power Transistors in a 2.5 MHz LLC DC/DC Converter for Compact and Efficient Power Conversion. In Proceedings of the 2016 18th European Conference on Power Electronics and Applications (EPE'16 ECCE Europe), Karlsruhe, Germany, 6-8 September 2016; Institute of Electrical and Electronics Engineers: Piscataway, NJ, USA, 2016; pp. 1-7.

2. Amirahmadi, A.; Domb, M.; Persson, E. High Power Density High Efficiency Wide Input Voltage Range LLC Resonant Converter Utilizing E-Mode GaN Switches. In Proceedings of the 2017 IEEE Applied Power Electronics Conference and Exposition (APEC), Tampa, FL, USA, 26-30 March 2017; Institute of Electrical and Electronics Engineers: Piscataway, NJ, USA, 2017 ; pp. 350-354.

3. Bhuvaneswari, C.; Samuel Rajesh Babu, R. A Review on LLC Resonant Converter. In Proceedings of the 2016 International Conference on Computation of Power, Energy Information and Communication (ICCPEIC), Melmaruvathur, India, 20-21 April 2016; Institute of Electrical and Electronics Engineers: Piscataway, NJ, USA, 2016; pp. 620-623.

4. Huang, H. Designing an LLC Resonant Half-Bridge Power Converter. In Texas Instruments Power Supply Design Seminar, SEM1900; Topic, 3; Texas Instruments Incorporated: Dallas, TX, USA, 2010; pp. 2010-2011.

5. Yang, B. Topology Investigation of Front End DC/DC Converter for Distributed Power System. Ph.D. Thesis, Department of Electrical and Computer Engineering, Virginia Tech, Blacksburg, VA, USA, 2003.

6. Wen, H.; Gong, J.; Yeh, C.-H.; Han, Y.; Lai, J. An Investigation on Fully Zero-Voltage-Switching Condition for High-Frequency GaN Based LLC Converter in Solid-State-Transformer Application. In Proceedings of the 2019 IEEE Applied Power Electronics Conference and Exposition (APEC), Anaheim, CA, USA, 17-21 March 2019; Institute of Electrical and Electronics Engineers: Piscataway, NJ, USA, 2019; pp. 797-801.

7. Choe, J.-M.; Yeth, C.-S.; Yu, O.; Lee, M.; Wen, H.; Lai, J.-S.; Zhang, L. Controller and EMI Filter Design for Modular Front-End Solid-State Transformer. In Proceedings of the 2018 IEEE Applied Power Electronics Conference and Exposition (APEC), San Antonio, TX, USA, 4-8 March 2018; Institute of Electrical and Electronics Engineers: Piscataway, NJ, USA, 2018 ; pp. 188-192.

8. Deng, J.; Li, S.; Hu, S.; Mi, C.C.; Ma, R. Design Methodology of LLC Resonant Converters for Electric Vehicle Battery Chargers. IEEE Trans. Veh. Technol. 2014, 63, 1581-1592. [CrossRef]

9. Chen, W.; Lu, Z.; Zhang, X.; Ye, S. A Novel ZVS Step-Up Push-Pull Type Isolated LLC Series Resonant Dc-Dc Converter for UPS Systems and Its Topology Variations. In Proceedings of the 2008 Twenty-Third Annual IEEE Applied Power Electronics Conference and Exposition, Austin, TX, USA, 24-28 February 2008; Institute of Electrical and Electronics Engineers: Piscataway, NJ, USA, 2008; pp. 1073-1078.

10. Zhao, X.; Zhang, L.; Born, R.; Lai, J.S. A High-Efficiency Hybrid Resonant Converter with Wide-Input Regulation for Photovoltaic Applications. IEEE Trans. Ind. Electron. 2017, 64, 3684-3695. [CrossRef]

11. Fei, C.; Gadelrab, R.; Li, Q.; Lee, F.C. High-frequency three-phase interleaved LLC resonant converter with GaN devices and integrated planar magnetics. IEEE J. Emerg. Sel. Top. Power Electron. 2019, 7, 653-663. [CrossRef]

12. Hsieh, H.; Wang, H.; Huang, T. LLC charger using quasi-contactless power transfer by resonant magnetic induction coupling. IEEE Trans. Transport. Electrific. 2018, 4, 376-388. [CrossRef]

13. Shen, Y.; Zhao, W.; Chen, Z.; Cai, C. Full-bridge LLC resonant converter with series-parallel connected transformers for electric vehicle on-board charger. IEEE Access 2018, 6, 13490-13500. [CrossRef]

14. Shi, C.; Wang, H.; Dusmez, S.; Khaligh, A. A SiC-based high efficiency isolated on-board PEV charger with ultra-wide DC-link voltage range. IEEE Trans. Ind. Appl. 2017, 53, 501-511. [CrossRef]

15. Shi, L.; Liu, B.; Duan, S. Current sharing method based on optimal phase shift control for interleaved three-phase half-bridge LLC converter with floating y-connection. J. Power Electron. 2019, 19, 934-943.

16. Lee, F.C.; Wang, S.; Kong, P.; Wang, C.; Fu, D. Power Architecture Design with Improved System Efficiency, EMI and Power Density. In Proceedings of the 2008 IEEE Power Electronics Specialists Conference, Rhodes, Greece, 15-19 June 2008; Institute of Electrical and Electronics Engineers: Piscataway, NJ, USA, 2008; pp. 4131-4137. 
17. Chen, R.; Brohlin, P.; Dapkus, D. Design and Magnetics Optimization of LLC Resonant Converter with GaN. In Proceedings of the 2017 IEEE Applied Power Electronics Conference and Exposition (APEC), Tampa, FL, USA, 26-30 March 2017; Institute of Electrical and Electronics Engineers: Piscataway, NJ, USA, 2017; pp. 94-98.

18. Yang, B.; Lee, F.C.; Zhang, A.J.; Huang, G. LLC Resonant Converter for Front end DC/DC Conversion. In Proceedings of the Seventeenth Annual IEEE Applied Power Electronics Conference and Exposition (IEEE APEC), Dallas, TX, USA, 10-14 March 2002; Institute of Electrical and Electronics Engineers: Piscataway, NJ, USA, 2002; pp. 1108-1112.

19. Yang, B.; Ren, Y.; Lee, F.C. Integrated Magnetic for LLC Resonant Converter. In Proceedings of the Seventeenth Annual IEEE Applied Power Electronics Conference and Exposition (IEEE APEC), Dallas, TX, USA, 10-14 March 2002; Institute of Electrical and Electronics Engineers: Piscataway, NJ, USA, 2002; pp. 346-351.

20. Lu, B.; Liu, W.; Liang, Y.; Lee, F.C.; van Wyk, J.D. Optimal Design Methodology for LLC Resonant Converter. In Proceedings of the Twenty-First Annual IEEE Applied Power Electronics Conference and Exposition (IEEE APEC), Dallas, TX, USA, 19-23 March 2006; Institute of Electrical and Electronics Engineers: Piscataway, NJ, USA, 2006; pp. 533-538.

21. Fu, D.; Lu, B.; Lee, F.C. 1 MHz High Efficiency LLC Resonant Converters with Synchronous Rectifier. In Proceedings of the 2007 IEEE Power Electronics Specialists Conference (IEEE PESC), Orlando, FL, USA, 17-21 June 2007; Institute of Electrical and Electronics Engineers: Piscataway, NJ, USA, 2007; pp. 2404-2410.

22. Fei, C. Optimization of LLC Resonant Converters: State-Trajectory Control and PCB based Magnetics. Ph.D. Thesis, Virginia Tech, Blacksburg, VA, USA, 2018.

23. Kozacek, B.; Frivaldsky, M.; Jaros, V. Improving Qualitative Parameters of LLC Converter Using a Perspective Semiconductor and Magnetic Components. In Proceedings of the 2016 International Conference on Applied Electronics (AE), Pilsen, Czech Republic, 6-7 September 2016; Institute of Electrical and Electronics Engineers: Piscataway, NJ, USA, 2016; pp. 125-129.

24. Fuhr, T.; Kupka, T. Innovative Single Stage Isolated AC/DC Converter with Power Factor Correction. In Proceedings of the 2019 20th International Scientific Conference on Electric Power Engineering (EPE), Kouty nad Desnou, Czech Republic, 15-17 May 2019; Institute of Electrical and Electronics Engineers: Piscataway, NJ, USA, 2019; pp. 1-4.

25. Qiu, Y.; Lu, L.J. High-Power-Density 400VDC-19VDC LLC Solution with GaN HEMTs. In Proceedings of the 20181 st Workshop on Wide Bandgap Power Devices and Applications in Asia (WiPDA Asia), Xi'an, China, 16-18 May 2018; Institute of Electrical and Electronics Engineers: Piscataway, NJ, USA, 2018; pp. 66-72.

26. Hu, Z.; Wang, L.; Qiu, Y.; Liu, Y.-F.; Sen, P.C. An Accurate Design Algorithm for LLC Resonant Converters Part II. IEEE Trans. Power Electron. 2016, 31, 5448-5460. [CrossRef]

27. Qiu, Y.; Wang, L.; Wang, H.; Liu, Y.; Sen, P.C. Bipolar Ripple Cancellation Method to Achieve Single-Stage Electrolytic-CapacitorLess High-Power LED Driver. IEEE J. Emerg. Sel. Top. Power Electron. 2015, 3, 698-713.

28. Qiu, Y.; Liu, W.; Fang, P.; Liu, Y.-F. A Mathematical Guideline for Designing an AC-DC LLC Converter with PFC. In Proceedings of the Thirty-Third Annual IEEE Applied Power Electronics Conference and Exposition (APEC 2018), San Antonio, TX, USA, 4-8 March 2018; Institute of Electrical and Electronics Engineers: Piscataway, NJ, USA, 2018; pp. 2001-2008.

29. Seeman, M.D.; Bahl, S.R.; Anderson, D.I.; Shah, G.A. Advantages of GaN in a High-Voltage Resonant LLC Converter. In Proceedings of the 2014 IEEE Applied Power Electronics Conference and Exposition (APEC 2014), Fort Worth, TX, USA, 16-20 March 2014; Institute of Electrical and Electronics Engineers: Piscataway, NJ, USA, 2014; pp. 476-483.

30. Reusch, D.; Lee, F.C. High Frequency Bus Converter with Low Loss Integrated Matrix Transformer. In Proceedings of the 2012 Twenty-Seventh Annual IEEE Applied Power Electronics Conference and Exposition (IEEE APEC), Orlando, FL, USA, 5-9 February 2012; Institute of Electrical and Electronics Engineers: Piscataway, NJ, USA, 2012; pp. 1392-1397.

31. Huang, D.; Ji, S.; Lee, F.C. LLC Resonant Converter with Matrix Transformer. IEEE Trans. Power Electron. 2014, $29,4339-4347$. [CrossRef]

32. Mu, M.; Lee, F.C. Design and Optimization of a 380-12 V High-Frequency, High-Current LLC Converter with GaN Devices and Planar Matrix Transformers. IEEE J. Emerg. Sel. Top. Power Electron. 2016, 4, 854-862.

33. Mojab, A.; Hemmat, Z.; Riazmontazer, H.; Rahnamaee, A. Introducing optical cascode GaN HEMT. IEEE Trans. Electron. Devices 2017, 64, 796-804. [CrossRef]

34. Fei, C.; Ahmed, M.H.; Lee, F.C.; Li, Q. Two-stage 48 V-12 V/6 V-1.8 V Voltage Regulator Module with Dynamic Bus Voltage Control for Light Load Efficiency Improvement of Two-stage Voltage Regulator. IEEE Trans. Power Electron. 2017, 32, 5628-5636. [CrossRef]

35. De Groot, H.; Janssen, E.; Pagano, R.; Schetters, K. Design of a 1-MHz LLC resonant converter based on a DSP-driven SOI half-bridge power MOS module. IEEE Trans. Power Electron. 2007, 22, 2307-2320. [CrossRef]

36. Fei, C.; Lee, F.C.; Li, Q. Digital Implementation of Soft Start-up and Short-circuit Protection for High-frequency LLC Converters with Optimal Trajectory Control (OTC). IEEE Trans. Power Electron. 2017, 32, 8008-8017. [CrossRef]

37. Fei, C.; Lee, F.C.; Li, Q. Multi-Step Simplified Optimal Trajectory Control (SOTC) for Fast Transient Response of High Frequency LLC Converters. In Proceedings of the 2015 IEEE Energy Conversion Congress and Exposition (IEEE ECCE 2015), Montreal, QC, Canada, 20-24 September 2015; Institute of Electrical and Electronics Engineers: Piscataway, NJ, USA, 2015; pp. $2064-2071$.

38. Fei, C.; Li, Q.; Lee, F.C. Digital Implementation of Adaptive Synchronous Rectifier (SR) Driving Scheme for High-frequency LLC Converters with Microcontroller. IEEE Trans. Ind. Electron. 2017, 33, 5351-5361. [CrossRef]

39. Fei, C.; Li, Q.; Lee, F.C. Digital implementation of light-load efficiency improvement for high-frequency LLC converters with simplified optimal trajectory control. IEEE J. Emerg. Sel. Top. Power Electron. 2018, 6, 1850-1859. [CrossRef] 
40. Lee, F.C.; Li, Q.; Liu, Z.; Yang, Y.; Fei, C.; Mu, M. Application of GaN devices for $1 \mathrm{~kW}$ server power supply with integrated magnetics. CPSS Trans. Power Electron. Appl. 2016, 1, 3-12. [CrossRef]

41. Tian, M.; Hao, Y.; Wang, K.; Xuan, Y.; Huang, L.; Sun, J.; Yang, X. EMI Modeling and Experiment of a GaN Based LLC Half-Bridge Converter. In Proceedings of the 2015 9th International Conference on Power Electronics and ECCE Asia (ICPE-ECCE Asia), Seoul, Korea, 1-5 June 2015; Institute of Electrical and Electronics Engineers: Piscataway, NJ, USA, 2015; pp. $1961-1966$.

42. Beiranvand, R.; Rashidian, B.; Zolghadri, M.R.; Hoseini Alavi, S.M. A design procedure for optimizing the LLC resonant converter as a wide output range voltage source. IEEE Trans. Power Electron. 2012, 27, 3749-3763. [CrossRef]

43. Beiranvand, R.; Rashidian, B.; Zolghadri, M.R.; Hoseini Alavi, S.M. Using LLC resonant converter for designing wide-range voltage source. IEEE Trans. Ind. Electron. 2011, 58, 1746-1756. [CrossRef]

44. Wang, H.; Dusmez, S.; Khaligh, A. Design and Analysis of a Full-Bridge LLC-Based PEV Charger Optimized for Wide Battery Voltage Range. IEEE Trans. Veh. Technol. 2014, 63, 1603-1613. [CrossRef]

45. Mishima, T.; Mizutani, H.; Nakaoka, M. A sensitivity-improved PFM LLC resonant full-bridge DC-DC converter with LC anti-resonant circuitry. IEEE Trans. Power Electron. 2017, 32, 310-324. [CrossRef]

46. Yeon, C.; Kim, J.; Park, M.; Lee, I.; Moon, G. Improving the light load regulation capability of LLC series resonant converter using impedance analysis. IEEE Trans. Power Electron. 2017, 32, 7056-7067. [CrossRef]

47. Li, C.; Wang, H.; Shang, M. A five-switch bridge based reconfigurable LLC converter for deeply depleted PEV charging applications. IEEE Trans. Power Electron. 2019, 34, 4031-4035. [CrossRef]

48. Kim, C.; Baek, J.; Lee, J. High-efficiency single-stage LLC resonant converter for wide-input-voltage range. IEEE Trans. Power Electron. 2018, 33, 7832-7840. [CrossRef]

49. Wu, H.; Zhan, X.; Xing, Y. Interleaved LLC resonant converter with hybrid rectifier and variable-frequency plus phase-shift control for wide output voltage range applications. IEEE Trans. Power Electron. 2017, 32, 4246-4257. [CrossRef]

50. Dung, N.A.; Chiu, H.; Lin, J.; Hsieh, Y.; Chen, H.; Zeng, B. Novel modulation of isolated bidirectional DC-DC converter for energy storage systems. IEEE Trans. Power Electron. 2019, 34, 1266-1275. [CrossRef]

51. Shahzad, M.I.; Iqbal, S.; Taib, S. Interleaved LLC converter with cascaded voltage-doubler rectifiers for deeply depleted PEV battery charging. IEEE Trans. Transport. Electrific. 2018, 4, 89-98. [CrossRef]

52. Shang, M.; Wang, H. A voltage-quadrupler rectifier based pulse width-modulated LLC converter with wide output range. IEEE Trans. Ind. Appl. 2018, 54, 6159-6168. [CrossRef]

53. Li, Z.; Xue, B.; Wang, H. An interleaved secondary-side modulated LLC resonant converter for wide output range applications. IEEE Trans. Ind. Electron. 2020, 67, 1124-1135. [CrossRef]

54. Wang, H.; Li, Z. A PWM LLC type resonant converter adapted to wide output range in PEV charging applications. IEEE Trans. Power Electron. 2018, 33, 3791-3801. [CrossRef]

55. Shang, M.; Wang, H.; Cao, Q. Reconfigurable LLC topology with squeezed frequency span for high-voltage bus-based photovoltaic systems. IEEE Trans. Power Electron. 2018, 33, 3688-3692. [CrossRef]

56. Tang, X.; Xing, Y.; Wu, H.; Zhao, J. An improved LLC resonant converter with reconfigurable hybrid voltage multiplier and PWM-plus-PFM hybrid control for wide output range applications. IEEE Trans. Power Electron. 2020, 35, 185-197. [CrossRef]

57. Sun, W.; Xing, Y.; Wu, H.; Ding, J. Modified high-efficiency LLC converters with two split resonant branches for wide input-voltage range applications. IEEE Trans. Power Electron. 2018, 33, 7867-7879. [CrossRef]

58. Dao, D.N.; Lee, D.-C. High-efficiency hybrid LLC resonant converter for on-board chargers of plug-in electric vehicles. IEEE Trans. Power Electron. 2020, 35, 8324-8334.

59. Matsumori, H.; Kosaka, T.; Sekido, K.; Kim, K.; Egawa, T.; Matsui, N. Isolated DC-DC Converter Utilizing GaN Power Device for Automotive Application. In Proceedings of the 2019 IEEE Applied Power Electronics Conference and Exposition (APEC), Anaheim, CA, USA, 17-21 March 2019; Institute of Electrical and Electronics Engineers: Piscataway, NJ, USA, 2019; pp. 1704-1709.

60. Wen, H.; Jiao, D.; Lai, J.-S.; Strydom, J.; Zhang, L. An Accurate Voltage Gain Model Considering Diode Effect for LLC Resonant Converter in Wide Gain Range Applications. In Proceedings of the 2020 IEEE Energy Conversion Congress and Exposition (ECCE), Detroit, MI, USA, 11-15 October 2020; Institute of Electrical and Electronics Engineers: Piscataway, NJ, USA, 2020; pp. 5436-5441.

61. Feng, W.; Lee, F.C.; Mattavelli, P. Optimal Trajectory Control of Burst Mode for LLC Resonant Converter. IEEE Trans. Power Electron. 2013, 28, 457-466. [CrossRef]

62. Wen, H.; Jiao, D.; Lai, J.-S. Light Load Operation Analysis for MHz GaN Based LLC Resonant Converter. In Proceedings of the 2020 IEEE 9th International Power Electronics and Motion Control Conference (IPEMC2020-ECCE Asia), Seoul, Korea, 1-5 June 2015; Institute of Electrical and Electronics Engineers: Piscataway, NJ, USA, 2015; pp. 1087-1090.

63. Cao, Q.; Li, Z.; Wang, H. Wide Voltage Gain Range LLC DC/DC Topologies: State-of-the-Art. In Proceedings of the 2018 International Power Electronics Conference (IPEC-Niigata 2018-ECCE Asia), Niigata, Japan, 20-24 May 2018; Institute of Electrical and Electronics Engineers: Piscataway, NJ, USA, 2018; pp. 100-107.

64. Bhalsod, S.K.; Bijeev, N.V.; Jani, V.H. Design and Simulation of Advanced GaN Based LLC Resonant Converter for Space Applications. In Proceedings of the 2017 International Conference on Current Trends in Computer, Electrical, Electronics and Communication (CTCEEC), Mysore, India, 8-9 September 2017; Institute of Electrical and Electronics Engineers: Piscataway, NJ, USA, 2017; pp. 733-739. 
65. Glitz, E.S.; Ordonez, M. MOSFET Power Loss Estimation in LLC Resonant Converters: Time Interval Analysis. IEEE Trans. Power Electron. 2019, 34, 11964-11980. [CrossRef]

66. De Simone, S.; Adragna, C.; Spini, C.; Gattavari, G. Design-oriented steady state analysis of LLC resonant converters based on FHA. In Proceedings of the SPEEDAM 2006 International Symposium on Power Electronics, Electrical Drives, Automation and Motion, Taormina, Italy, 23-26 May 2006.

67. Infineon Technologies North America (IFNA) Corp. Resonant LLC Converter: Operation and Design; Application Note AN201209V1.0; Infineon Technologies North America (IFNA) Corp: Los Angeles, CA, USA, 2012.

68. Ren, R.; Liu, B.; Jones, E.A.; Wang, F.; Zhang, Z.; Costinett, D. Accurate ZVS Boundary in High Switching Frequency LLC Converter. In Proceedings of the 2016 IEEE Energy Conversion Congress and Exposition (ECCE), Milwaukee, WI, USA, 18-22 September 2016; Institute of Electrical and Electronics Engineers: Piscataway, NJ, USA, 2016; pp. 1-6.

69. Chen, H.; Wu, X. Analysis on the Influence of the Secondary Parasitic Capacitance to ZVS Transient in LLC Resonant Converter. In Proceedings of the 2014 IEEE Energy Conversion Congress and Exposition (ECCE), Pittsburgh, PA, USA, 14-18 September 2014; Institute of Electrical and Electronics Engineers: Piscataway, NJ, USA, 2014; pp. 4755-4760.

70. Wen, H.; Gong, J.; Zhao, X.; Yeh, C.; Lai, J. Analysis of Diode Reverse Recovery Effect on ZVS Condition for GaN-Based LLC Resonant Converter. IEEE Trans. Power Electron. 2019, 34, 11952-11963. [CrossRef]

71. Liu, J.X.; Yushyna, L. High Frequency Investigation of Wide Bandgap-based PFC and LLC Converters in PSU. In Proceedings of the PCIM Europe Digital Days 2020: International Exhibition and Conference for Power Electronics, Intelligent Motion, Renewable Energy and Energy Management, Frankfurt on the Main, Germany, 7-8 July 2020; VDE: Frankfurt on the Main, Germany; pp. 1-7.

72. Strain, N.N.; Sun, J.; Huang, X.; Costinett, D.J.; Tolbert, L.M. ZVS Analysis of a GaN-Based Series-Parallel Dual Transformer LLC Resonant Converter. In Proceedings of the 2019 IEEE 7th Workshop on Wide Bandgap Power Devices and Applications (WiPDA), Raleigh, NC, USA, 29-31 October 2019; Institute of Electrical and Electronics Engineers: Piscataway, NJ, USA, 2019 ; pp. 398-404.

73. Lee, B.; Kim, M.; Kim, C.; Park, K.; Moon, G. Analysis of LLC Resonant Converter Considering Effects of Parasitic Components. In Proceedings of the 31st International Telecommunications Energy Conference, Incheon (INTELEC 2009), Incheon, Korea, 18-22 October 2009; Institute of Electrical and Electronics Engineers: Piscataway, NJ, USA, 2009; pp. 1-6.

74. Wen, H.; Liu, Y.; Lai, J.-S. Analysis on the Effect of Secondary Side Devices for the Operation of GaN Based LLC Resonant Converter. In Proceedings of the 2020 IEEE Applied Power Electronics Conference and Exposition (APEC), New Orleans, LA, USA, 15-19 March 2020; Institute of Electrical and Electronics Engineers: Piscataway, NJ, USA, 2020; pp. $2214-2218$.

75. Wen, H.; Jiao, D.; Lai, J.-S. Optimal Design Methodology for High Frequency GaN Based Step-up LLC Resonant Converter. In Proceedings of the 2019 IEEE 4th International Future Energy Electronics Conference (IFEEC), Singapore, 25-28 November 2019; Institute of Electrical and Electronics Engineers: Piscataway, NJ, USA, 2019; pp. 1-5.

76. Wang, N.; Jia, H.; Tian, M.; Li, Z.; Xu, G.; Yang, X. Impact of Transformer Stray Capacitance on the Conduction Loss in a GaN-Based LLC Resonant Converter. In Proceedings of the 2017 IEEE 3rd International Future Energy Electronics Conference and ECCE Asia (IFEEC 2017-ECCE Asia), Kaohsiung, Taiwan, 3-7 June 2017; Institute of Electrical and Electronics Engineers: Piscataway, NJ, USA, 2017; pp. 1334-1338.

77. Prieto, M.J.; Fernandez, A.; Diaz, J.M.; Lopera, J.M.; Sebastian, J. Influence of Transformer Parasitics in Low-Power Applications. In Proceedings of the Fourteenth Annual Applied Power Electronics Conference and Exposition (APEC '99), Dallas, TX, USA, 14-18 March 1999; Institute of Electrical and Electronics Engineers: Piscataway, NJ, USA, 1999; pp. 1175-1180.

78. Lu, H.-Y.; Zhu, J.-G.; Hui, S.Y.R. Experimental determination of stray capacitances in high frequency transformers. IEEE Trans. Power Electron. 2003, 18, 1105-1112.

79. Saket, M.A.; Shafiei, N.; Ordonez, M.; Craeiun, M.; Botting, C. Low Parasitics Planar Transformer for LLC Resonant Battery Chargers. In Proceedings of the IEEE Applied Power Electronics Conference and Exposition, Long Beach, CA, USA, 20-24 March 2016; Institute of Electrical and Electronics Engineers: Piscataway, NJ, USA, 2016; pp. 854-858.

80. Kong, P.; Wang, S.; Lee, F.C.; Wang, Z. Reducing Common-Mode Noise in Two-Switch Forward Converter. IEEE Trans. Power. Electron. 2011, 26, 1522-1533. [CrossRef]

81. Zhang, W.; Long, Y.; Cui, Y.; Wang, F.; Tolbert, L.M.; Blalock, B.J.; Henning, S.; Moses, J.; Dean, R. Impact of Planar Transformer Winding Capacitance on Si-Based and GaN-Based LLC Resonant Converter. In Proceedings of the 2013 Twenty-Eighth Annual IEEE Applied Power Electronics Conference and Exposition (APEC), Long Beach, CA, USA, 17-21 March 2013; Institute of Electrical and Electronics Engineers: Piscataway, NJ, USA, 2013; pp. 1668-1674.

82. Watanabe, T.; Oshikata, T.; Nishijima, K.; Kurokawa, F. A New Approach of Improvement of Dissipation Caused by Capacitance between Primary and Secondary Windings of LLC Transformer. In Proceedings of the 2015 International Conference on Renewable Energy Research and Applications (ICRERA), Palermo, Italy, 22-25 November 2015; Institute of Electrical and Electronics Engineers: Piscataway, NJ, USA, 2015; pp. 484-488.

83. Saket, M.A.; Shafiei, N.; Ordonez, M. LLC converters with planar transformers: Issues and mitigation. IEEE Trans. Power Electron. 2016, 32, 4524-4542. [CrossRef]

84. Chen, Y.; Lee, F.; Amoroso, L.; Wu, H.P. A Resonant MOSFET Gate Driver with Efficient Energy Recovery. IEEE Trans. Power Electron. 2004, 19, 470-477. [CrossRef]

85. Eberle, W.; Zhang, Z.; Liu, Y.F.; Sen, P.C. A Current Source Gate Driver Achieving Switching Loss Savings and Gate Energy Recovery at 1-MHz. IEEE Trans. Power Electron. 2008, 23, 678-691. [CrossRef] 
86. Pereira, D.; de Paula, W.; Braga, H. SPICE Simulation and Evaluation of a GaN-Based Synchronous Full-Bridge Resonant Converter. In Proceedings of the 12th IEEE International Conference on Industry Applications (INDUSCON), Curitiba, Brazil, 20-23 November 2016.

87. Wang, K.; Yang, X.; Wang, L.; Jain, P. Instability Analysis and Oscillation Suppression of Enhancement-Mode GaN Devices in Half-Bridge Circuits. IEEE Trans. Power Electron. 2018, 33, 1585-1596. [CrossRef]

88. Yu, J.S.; Zhang, W.J.; Ng, W.T. A Segmented Output Stage H-bridge IC with Tunable Gate Driver. In Proceedings of the 2014 IEEE 26th International Symposium on Power Semiconductor Devices \& IC's (ISPSD), Waikoloa, HI, USA, 15-19 June 2014.

89. Zhang, W.J.; Leng, Y.; Yu, J.S.; Jiang, X.X.; Cheng, C.Y.; Ng, W.T. A Gate Driver IC for Enhancement Mode GaN Power Transistors with Sense FET Reverse Conduction Detection Circuit. IET Power Electron. 2019, 12, 3928-3935. [CrossRef]

90. Long, Y.; Zhang, W.; Costinett, D.; Blalock, B.B.; Jenkins, L.L. A High-Frequency Resonant Gate Driver for Enhancement-Mode GaN Power Devices. In Proceedings of the 2015 IEEE Applied Power Electronics Conference and Exposition (APEC), Charlotte, NC, USA, 15-19 March 2015.

91. Zhang, Z.; Yang, Z.; Ye, S.; Liu, Y.-F. Topology and Analysis of a New Resonant Gate Driver. In Proceedings of the PESC Record-IEEE Annual Power Electronics Specialists Conference, Jeju, Korea, 18-22 June 2006.

92. Eberle, W.; Sen, P.C.; Liu, Y.-F. A New Resonant Gate Drive Circuit with Efficient Energy Recovery and Low Conduction Loss. IEEE Trans. Ind. Electron. 2008, 55, 2213-2221. [CrossRef]

93. ON Semiconductor. High Speed Half-Bridge Driver for GaN Power Switches; NCP51820; Semiconductor Components Industries, LLC.: Phoenix, AZ, USA, 2021.

94. GaN Systems. Design with GaN Enhancement Mode HEMT: GN001 Application Guide; GaN Systems Inc.: Kanata, ON, Canada, 2016.

95. Infineon. Single-Channel Functional and Reinforced Isolated Gate-Drive ICs for High-Voltage Enhancement-Mode GaN HEMTs; GaN EiceDRIVER Product Family; Infineon: Neubiberg, Germany, 2019.

96. Yi, K.H.; Moon, G.W. Novel two-phase interleaved LLC series-resonant converter using a phase of the resonant capacitor. IEEE Trans. Ind. Electron. 2009, 56, 1815-1819.

97. Hu, Z.; Qiu, Y.; Wang, L.; Liu, Y.F. An Interleaved LLC Resonant Converter Operating at Constant Switching Frequency. IEEE Trans. Power Electron. 2014, 29, 2931-2943. [CrossRef]

98. Hu, Z.; Qiu, Y.; Liu, Y.F.; Sen, P.C. A control strategy and design method for interleaved LLC converters operating at variable switching frequency. IEEE Trans. Power Electron. 2014, 29, 4426-4437. [CrossRef]

99. Kirshenboim, O.; Peretz, M.M. Combined Multi-Level and Two-phase Interleaved LLC Converter with Enhanced Power Processing Characteristics and Natural Current Sharing. IEEE Trans. Power Electron. 2018, 33, 5613-5620. [CrossRef]

100. Orietti, E.; Mattavelli, P.; Spiazzi, G.; Adragna, C.; Gattavari, G. Current Sharing in Three-Phase LLC Interleaved Resonant Converter. In Proceedings of the 2009 IEEE Energy Conversion Congress and Exposition (IEEE ECCE 2009), San Jose, CA, USA, 20-24 September 2009; Institute of Electrical and Electronics Engineers: Piscataway, NJ, USA, 2009; pp. 1145-1152.

101. Kim, H.S.; Baek, J.W.; Ryu, M.H.; Kim, J.H.; Jung, J.H. The high-efficiency isolated ac-dc converter using the three-phase interleaved LLC resonant converter employing the Y-connected rectifier. IEEE Trans. Power Electron. 2014, 29, 4017-4028. [CrossRef]

102. Yang, H.; Pei, C.; Liang, Y. Magnetic Integrated Device and Power Conversion Circuit. U.S. Patent Application No. 15/147,589, 22 January 2019.

103. Boysen, K.; Myhre, R. Resonant Circuit and Resonant DC/DC Converter. U.S. Patent US9240723B2, 19 January 2016.

104. Nakakohara, Y.; Otake, H.; Evans, T.M.; Yoshida, T.; Tsuruya, M.; Nakahara, K. Three-phase LLC series resonant DC/DC converter using SiC MOSFETs to realize high-voltage and high-frequency operation. IEEE Trans. Ind. Electron. 2016, 63, 2103-2110. [CrossRef]

105. Tengfei, O.; Noah, M.; Tsuruya, M.; Namiki, S.; Morita, K.; Imaoka, J.; Yamamoto, M. Transformer with Adjustable Path-Core Type Inductance for Use in GaN-HEMT LLC Resonant Converter. IEEJ J. Ind. Appl. 2021, 21002488. [CrossRef]

106. Mostafa, N.; Kimura, S.; Imaoka, J.; Martinez, W.; Endo, S.; Yamamoto, M.; Umetani, K. Magnetic design and experimental evaluation of a commercially available single integrated transformer in three-phase LLC resonant converter. IEEE Trans. Ind. Appl. 2018, 54, 6190-6204.

107. Mostafa, N.; Umetani, K.; Endo, S.; Ishibashi, H.; Imaoka, J.; Yamamoto, M. A Lagrangian dynamics model of integrated transformer incorporated in a multi-phase LLC resonant converter. In Proceedings of the 2017 IEEE Energy Conversion Congress and Exposition (ECCE), Cincinnati, OH, USA, 1-5 October 2017; Institute of Electrical and Electronics Engineers: Piscataway, NJ, USA, 2017; pp. 3781-3787.

108. Mostafa, N.; Umetani, K.; Imaoka, J.; Yamamoto, M. Lagrangian dynamics model and practical implementation of an integrated transformer in multi-phase LLC resonant converter. IET Power Electron. 2018, 11, 339-347.

109. Mostafa, N.; Endo, S.; Ishibashi, H.; Nanamori, K.; Imaoka, J.; Umetani, K.; Yamamoto, M. A current sharing method utilizing single balancing transformer for a multiphase LLC resonant converter with integrated magnetics. IEEE J. Emerg. Sel. Top. Power Electron. 2017, 6, 977-992.

110. Krigar, T.; Pfost, M. 2-MHz Compact Wireless Power Transfer System with Voltage Conversion From 400 V to 48 V. In Proceedings of the 2021 IEEE Wireless Power Transfer Conference (WPTC), San Diego, CA, USA, 1-4 June 2021; Institute of Electrical and Electronics Engineers: Piscataway, NJ, USA, 2021; pp. 1-4. 
111. Ziyi, J.; Min, F.; Dou, Y.; Cao, Z.; Li, X. Optimization of key power loss for LLC circuits with planar transformer in high-frequency and high-power scenarios. AIP Adv. 2021, 11, 055119.

112. Li, B.; Li, Q.; Lee, F.C. High-Frequency PCB Winding Transformer with Integrated Inductors for a Bi-Directional Resonant Converter. IEEE Trans. Power Electron. 2019, 34, 6123-6135. [CrossRef]

113. Fei, C.; Lee, F.C.; Li, Q. High-Efficiency High-Power-Density LLC Converter with an Integrated Planar Matrix Transformer for High-Output Current Applications. IEEE Trans. Ind. Electron. 2017, 64, 9072-9082. [CrossRef]

114. Runruo, C.; Yu, S.-Y. A High-Efficiency High-Power-Density 1MHz LLC Converter with GaN Devices and Integrated Transformer. In Proceedings of the 2018 IEEE Applied Power Electronics Conference and Exposition (APEC), San Antonio, TX, USA, 4-8 March 2018; Institute of Electrical and Electronics Engineers: Piscataway, NJ, USA, 2018; pp. 791-796.

115. Yan, C.; Li, F.; Zeng, J.; Liu, T.; Ying, J. A Novel Transformer Structure for High Power, High Frequency Converter. In Proceedings of the 2007 IEEE Power Electronics Specialists Conference, Orlando, FL, USA, 17-21 June 2007; Institute of Electrical and Electronics Engineers: Piscataway, NJ, USA, 2007; pp. 214-218.

116. Huang, D.; Ji, S.; Lee, F.C. LLC Resonant Converter with Matrix Transformer. In Proceedings of the 2014 IEEE Applied Power Electronics Conference and Exposition (APEC 2014), Fort Worth, TX, USA, 16-20 March 2014; Institute of Electrical and Electronics Engineers: Piscataway, NJ, USA, 2014; pp. 1118-1125.

117. Ren, R.; Liu, S.; Wang, J.; Zhang, F. High Frequency LLC DC-Transformer Based on GaN Devices and the Dead Time Optimization. In Proceedings of the 2014 International Power Electronics and Application Conference and Exposition, Shanghai, China, 5-8 November 2014; Institute of Electrical and Electronics Engineers: Piscataway, NJ, USA, 2014; pp. 462-467.

118. Hu, J.; Sullivan, C.R. Optimization of Shapes for Round-Wire High Frequency Gapped-Inductor Windings. In Proceedings of the 1998 IEEE Industry Applications Society Annual Meeting, St. Louis, MO, USA, 12-15 October 1998; Institute of Electrical and Electronics Engineers: Piscataway, NJ, USA, 1998; pp. 900-906.

119. Pollock, J.D.; Sullivan, C.R. Modelling Foil Winding Configurations with Low AC and DC Resistance. In Proceedings of the 2005 IEEE 36th Power Electronics Specialists Conference, Recife, Dresden, Germany, 16 June 2005; Institute of Electrical and Electronics Engineers: Piscataway, NJ, USA, 2005; pp. 1507-1512.

120. Wen, H.; Liu, Y.; Jiao, D.; Yeh, C.-S.; Lai, J.-S. Design Principles and Optimization Considerations of a High Frequency Transformer in GaN Based $1 \mathrm{MHz} 2.8 \mathrm{~kW}$ LLC Resonant Converter with over 99\% Efficiency. In Proceedings of the 2021 IEEE Applied Power Electronics Conference and Exposition (APEC), Phoenix, AZ, USA, 14-17 June 2021; Institute of Electrical and Electronics Engineers: Piscataway, NJ, USA, 2021; pp. 1939-1944.

121. Liu, Y.; Wen, H.; Dung, N.A.; Lai, J. Design Considerations for MHz PCB Winding Magnetic Components. In Proceedings of the 2019 IEEE 4th International Future Energy Electronics Conference (IFEEC), Singapore, 25-28 November 2019; Institute of Electrical and Electronics Engineers: Piscataway, NJ, USA, 2019; pp. 1-8.

122. Lidow, A.; Strydom, J.; Strittmatter, R.; Zhou, C. GaN: A Reliable Future in Power Conversion. IEEE Power Electron. Mag. 2015, 2, 20-26. [CrossRef]

123. Ribarich, T.; Bredemeier, P.; Oliver, S. GaN High Density 300W AC-DC Converter. In Proceedings of the PCIM Europe 2019: International Exhibition and Conference for Power Electronics, Intelligent Motion, Renewable Energy and Energy Management, Nuremberg, Germany, 7-9 May 2019; VDE: Frankfurt on the Main, Germany, 2019; pp. 1-4.

124. Lee, I.; Moon, G. Analysis and Design of a Three-Level LLC Series Resonant Converter for High- and Wide-Input-Voltage Applications. IEEE Trans. Power Electron. 2012, 27, 2966-2979. [CrossRef]

125. Haga, H.; Kurokawa, F. Modulation Method of a Full-Bridge Three-Level LLC Resonant Converter for Battery Charger of Electrical Vehicles. IEEE Trans. Power Electron. 2017, 32, 2498-2507. [CrossRef]

126. Feng, Q.; Wang, Z.; Wu, Y.; Zuk, P. 900V GaN FETs in a 300 kHz 2 kW LLC Converter for High Input Voltage Applications. In Proceedings of the 2019 IEEE 7th Workshop on Wide Bandgap Power Devices and Applications (WiPDA), Raleigh, NC, USA, 29-31 October 2019; Institute of Electrical and Electronics Engineers: Piscataway, NJ, USA, 2019; pp. 388-392.

127. Ruiyang, Y.; Huang, Q.; Chen, T.; Huang, A.Q.; Ribarich, T. High-Frequency and High-Density Design of All GaN Power Supply Unit. In Proceedings of the PCIM Europe 2018: International Exhibition and Conference for Power Electronics, Intelligent Motion, Renewable Energy and Energy Management, Nuremberg, Germany, 5-7 June 2018; VDE: Frankfurt on the Main, Germany, 2018; pp. 1-5.

128. Ribarich, T.; Oliver, S. State-of-The-Art GaN Power IC-Based 150 W AC-DC Adapter. In Proceedings of the PCIM Europe 2017: International Exhibition and Conference for Power Electronics, Intelligent Motion, Renewable Energy and Energy Management, Nuremberg, Germany, 16-18 May 2017; VDE: Frankfurt on the Main, Germany, 2017; pp. 1-7.

129. Lee, J.Y.; Jeong, Y.S.; Han, B.M. An Isolated DC/DC Converter Using High-Frequency Unregulated LLC Resonant Converter for Fuel Cell pplications. IEEE Trans. Ind. Electron. 2011, 58, 2926-2934. [CrossRef]

130. Wienhausen, A.H.; Kranzer, D. 1 MHz Resonant DC/DC-Converter Using 600 V Gallium Nitride (GaN) Power Transistors. Mater. Sci. Forum 2013, 740-742, 1123-1127. [CrossRef]

131. Ruiyang, Y.; Huang, Q.; Ribarich, T.; Huang, A.Q.; Kinzer, D. Monolithic GaN Power ICs Enable High Density High Frequency $3.2 \mathrm{~kW}$ AC-DC Rectifier. In Proceedings of the PCIM Europe 2018: International Exhibition and Conference for Power Electronics, Intelligent Motion, Renewable Energy and Energy Management, Nuremberg, Germany, 5-7 June 2018; VDE: Frankfurt on the Main, Germany, 2018; pp. 1-4. 
132. Youhao, X.; Min, C.; Nielson, K.; Bell, R. Optimization of the Drive Circuit for Enhancement Mode Power GaN FETs in DC-DC Converters. In Proceedings of the Applied Power Electronics Conference and Exposition (APEC), 2012 Twenty-Seventh Annual IEEE, Orlando, FL, USA, 5-9 February 2012; Institute of Electrical and Electronics Engineers: Piscataway, NJ, USA, 2012; pp. 2467-2471.

133. Sun, T.; Ren, X.; Chen, Q.; Zhang, Z.; Ruan, X. Reliability and Efficiency Improvement in LLC Resonant Converter by Adopting GaN Transistor. In Proceedings of the 2015 IEEE Applied Power Electronics Conference and Exposition (APEC '2015), Charlotte, NC, USA, 15-19 March 2015; Institute of Electrical and Electronics Engineers: Piscataway, NJ, USA, 2015; pp. $2459-2463$.

134. Park, H.P.; Jung, J.H. Design Considerations of 1 MHz LLC Resonant Converter with GaN E-HEMT. In Proceedings of the 17th European Conference on Power Electronics and Applications (EPE'15 ECCE-Europe), Geneva, Switzerland, 8-10 September 2015.

135. Hariya, A.; Matsuura, K.; Yanagi, H.; Tomioka, S.; Ishizuka, Y.; Ninomiya, T. 5 MHz PWM-Controlled Current Mode Resonant DC-DC Converter Using GaN-FETs. In Proceedings of the 2014 International Power Electronics Conference (IPEC-Hiroshima 2014-ECCE-ASIA), Hiroshima, Japan, 18-21 May 2014; Institute of Electrical and Electronics Engineers: Piscataway, NJ, USA, 2014; pp. 3630-3637.

136. Liang, W.; Raymond, L.; Gu, L.; Rivas, J. 27.12 MHz GaN Resonant Power Converter with PCB Embedded Resonant Air Core Inductors and Capacitors. In Proceedings of the 2015 IEEE Energy Conversion Congress and Exposition (ECCE), Montreal, QC, Canada, 20-24 September 2015; Institute of Electrical and Electronics Engineers: Piscataway, NJ, USA, 2015; pp. 4251-4256.

137. Shigematsu, H.; Inoue, Y.; Akasegawa, A.; Yamada, M.; Masuda, S.; Kamada, Y.; Yamada, A.; Kanamura, M.; Ohki, T.; Makiyama, K.; et al. C-Band 340W and X-Band 100W GaN Power Amplifiers with Over 50\% PAE. In Proceedings of the IEEE MTT-S International Microwave Symposium Digest, Boston, MA, USA, 7-12 June 2009; Institute of Electrical and Electronics Engineers: Piscataway, NJ, USA, 2009; pp. 1265-1268.

138. Micovic, M.; Kurdoghlian, A.; Shinohara, K.; Burnham, S.; Milosavljevic, I.; Hu, M.; Corrion, A.; Fung, A.; Lin, R.; Samoska, L.; et al. W-Band GaN MMIC with $842 \mathrm{~mW}$ Output Power at $88 \mathrm{GHz}$. In Proceedings of the IEEE MTT-S International Microwave Symposium Digest, Anaheim, CA, USA, 23-28 May 2010; Institute of Electrical and Electronics Engineers: Piscataway, NJ, USA, 2010; pp. 237-239.

139. Yang, Y.; Liu, Z.; Lee, F.C.; Li, Q. Analysis and Filter Design of Differential Mode EMI Noise for GaN-Based Interleaved MHz Critical Mode PFC Converter. In Proceedings of the 2014 IEEE Energy Conversion Congress and Exposition (ECCE), Pittsburgh, PA, USA, 14-18 September 2014; Institute of Electrical and Electronics Engineers: Piscataway, NJ, USA, 2014; pp. 4784-4789.

140. Mausamjeet, K.; Pervaiz, S.; Afridi, K.K. Control of a Merged-Energy-Buffer Based Two-Stage Electrolytic-Free Offline LED Driver. In Proceedings of the 2019 20th Workshop on Control and Modeling for Power Electronics (COMPEL), Toronto, ON, Canada, 17-20 June 2019; Institute of Electrical and Electronics Engineers: Piscataway, NJ, USA, 2019; pp. 1-6.

141. Ionascut-Nedelcescu, A.; Carlone, C.; Houdayer, A.; von Bardeleben, J.H.; Cantin, J.L.; Raymond, S. Radiation hardness of gallium nitride. IEEE Trans. Nucl. Sci. 2002, 49, 2733-2738. [CrossRef]

142. Adell, P.C.; Scheick, L.Z. Radiation Effects in Power Systems: A Review. IEEE Trans. Nucl. Sci. 2013, 60, 1929-1952. [CrossRef]

143. Maier, D.; Alomari, M.; Grandjean, N.; Carlin, J.; Diforte-Poisson, M.; Dua, C.; Delage, S.; Kohn, E. InAlN/GaN HEMTs for operation in the $1000{ }^{\circ} \mathrm{C}$ regime: A first experiment. IEEE Electron. Device Lett. 2012, 33, 985-987. [CrossRef]

144. Stocco, A. Reliability and Failure Mechanisms of GaN HEMT Devices Suitable for High-Frequency and High-Power Applications. Ph.D. Thesis, University of Padova, Padova, Italy, 2012.

145. Meneghesso, G.; Meneghini, M.; Tazzoli, A.; Ronchi, N.; Stocco, A.; Chini, A.; Zanoni, E. Reliability issues of Gallium Nitride High Electron Mobility Transistors. Int. J. Microw. Wirel. Technol. 2006, 2, 39-50. [CrossRef]

146. Shigekawa, N.; Shiojima, K.; Suemitsu, T. Electroluminescence characterization of AlGaN/GaN high-electron-mobility transistors. Appl. Phys. Lett. 2001, 79, 1196-1198. [CrossRef]

147. Shigekawa, N.; Shiojima, K.; Suemitsu, T. Optical study of high-biased AlGaN/GaN high-electron-mobility transistors. J. Appl. Phys. 2002, 92, 531-535. [CrossRef]

148. Meneghesso, G.; Verzellesi, G.; Danesin, F.; Rampazzo, F.; Zanon, F.; Tazzoli, A.; Meneghini, M.; Zanoni, E. Reliability of GaN High-Electron-Mobility Transistors: State of the art and perspectives. IEEE Trans. Device Mater. Reliab. 2008, 8, 332-343. [CrossRef]

149. Coffie, R.; Chen, Y.; Smorchkova, I.P.; Heying, B.; Gambin, V.; Sutton, W.; Chou, Y.C.; Luo, W.-B.; Wojtowicz, M.; Oki, A. Temperature and Voltage Dependent RF Degradation Study in AlGaN/GaN HEMTs. In Proceedings of the IEEE International Reliability Physics Symposium, Phoenix, AZ, USA, 15-19 April 2007; Institute of Electrical and Electronics Engineers: Piscataway, NJ, USA, 2007; pp. 568-569.

150. Vetury, R.; Zhang, N.Q.; Keller, S.; Mishra, U.K. The impact of surface states on the DC and RF characteristics of AlGaN/GaN HFETs. IEEE Trans. Electron. Devices 2001, 48, 560-566. [CrossRef]

151. Chini, A.; Buttari, D.; Coffie, R.; Shen, L.; Heikman, S.; Chakraborty, A.; Keller, S.; Mishra, U.K. High Performance AlGaN/GaN HEMTs with a Field Plated Gate Structure. In Proceedings of the International Semiconductor Device Research Symposium, Washington, DC, USA, 10-12 December 2003; Institute of Electrical and Electronics Engineers: Piscataway, NJ, USA, 2003; pp. 434-435.

152. Zanoni, E.; Meneghini, M.; Chini, A.; Marcon, D.; Meneghesso, G. AlGaN/GaN-based HEMTs failure physics and reliability: Mechanisms affecting gate edge and Schottky junction. IEEE Trans. Electron. Devices 2013, 60, 3119-3131. [CrossRef]

153. Abbate, C.; Busatto, G.; Sanseverino, A.; Tedesco, D.; Velardi, F. Failure mechanisms of enhancement mode GaN power HEMTs operated in short circuit. Microelectron. Reliab. 2019, 100-101, 113454. [CrossRef] 
154. Abbate, C.; Busatto, G.; Sanseverino, A.; Tedesco, D.; Velardi, F. Failure analysis of 650 V enhancement mode GaN HEMT after short circuit tests. Microelectron. Reliab. 2018, 88-90, 677-683. [CrossRef]

155. Abbate, C.; Busatto, G.; Sanseverino, A.; Tedesco, D.; Velardi, F. Experimental study of the instabilities observed in $650 \mathrm{~V}$ enhancement mode GaN HEMT during short circuit. Microelectron. Reliab. 2017, 76-77, 314-320. [CrossRef]

156. Abbate, C.; Colella, L.; di Folco, R.; Busatto, G.; Martano, E.; Palazzo, S.; Sanseverino, A.; Velardi, F. An Accurate Switching Current Measurement Based on Resistive Shunt Applied to Short Circuit GaN HEMT Characterization. Appl. Sci. 2021, 11, 9138. [CrossRef]

157. Mao, M.; Tang, S.; Wang, Z.; Deng, R.; Deng, C.; Chen, S.; Ren, Y. Effect of Temperature Cycling, High Temperature Storage and Steady-State Operation Life Test on Reliability of GaN HEMTs. In Proceedings of the 2021 22nd International Conference on Electronic Packaging Technology (ICEPT), Xiamen, China, 14-17 September 2021; Institute of Electrical and Electronics Engineers: Piscataway, NJ, USA, 2021; pp. 1-4.

158. Zeng, C.; Wang, Y.; Liao, X.; Li, R.; Chen, Y.; Lai, P.; Huang, Y.; En, Y. Reliability Assessment of Algangan Hemts for High Voltage Applications Based on High Temperature Reverse Bias Test. In Proceedings of the 2014 10th International Conference on Reliability, Maintainability and Safety (ICRMS), Guangzhou, China, 6-8 August 2014; Institute of Electrical and Electronics Engineers: Piscataway, NJ, USA, 2014; pp. 298-301. 